\title{
Disease- and treatment-associated acquired glucocorticoid resistance
}

\author{
Legh Wilkinson, Nicolette J D Verhoog and Ann Louw \\ Department of Biochemistry, Stellenbosch University, Stellenbosch, South Africa \\ Correspondence should be addressed to A Louw: al@sun.ac.za
}

\begin{abstract}
The development of resistance to glucocorticoids (GCs) in therapeutic regimens poses a major threat. Generally, GC resistance is congenital or acquired over time as a result of disease progression, prolonged GC treatment or, in some cases, both. Essentially, disruptions in the function and/or pool of the glucocorticoid receptor $\alpha(G R \alpha)$ underlie this resistance. Many studies have detailed how alterations in GRo function lead to diminished GC sensitivity; however, the current review highlights the wealth of data concerning reductions in the GR $\alpha$ pool, mediated by disease-associated and treatmentassociated effects, which contribute to a significant decrease in GC sensitivity.

Additionally, the current understanding of the molecular mechanisms involved in driving reductions in the GR $\alpha$ pool is discussed. After highlighting the importance of maintaining the level of the GRo pool to combat GC resistance, we present current strategies and argue that future strategies to prevent GC resistance should involve biased ligands with a predisposition for reduced GR dimerization, a strategy originally proposed as the SEMOGRAM-SEDIGRAM concept to reduce the side-effect profile of GCs.
\end{abstract}

\author{
Key Words \\ - glucocorticoid receptor \\ - glucocorticoid resistance \\ - acquired resistance \\ - biased ligands \\ - GR $\alpha$ downregulation
}

\section{Introduction}

Due to the interrelatedness of the stress and inflammatory responses, chronic persistent inflammation may be considered both a cause and a consequence of a prolonged disruption of the central HPA axis, a systemic signalling pathway of the stress response (1). This in turn, has many peripheral effects, such as an increase in circulating glucocorticoids (GCs) $(2,3)$.

Chronic stress or prolonged exogenous GC treatment also disrupts the central homeostatic nature of GC signalling, often resulting in various peripheral effects, one of which is the tissue-specific reductions in the glucocorticoid receptor $\alpha(G R \alpha)$ functional pool. This reduction in the GRo functional pool may ultimately drive the development of acquired GC resistance and result in the progression of many psychological and pathological conditions.

Endogenous GCs, which are regulated by the HPA axis, are physiological mediators secreted in an ultradian or circadian manner (3) or in response to internal or external signals $(2,3,4,5,6)$, such as infection, pain or stress, and function within the body to regulate inflammation and maintain internal homeostasis $(2,3,6,7)$. Exogenous GCs, designed to mimic the biological anti-inflammatory action of endogenous GCs, remain the mainstay therapeutic choice (7) for the treatment of chronic inflammation in various psychological and pathological conditions. GCs are currently one of the most widely prescribed drugs in the world with an estimated $1.2 \%$ of the population of the United States, using them (8). Although effective antiinflammatory agents, it is believed that approximately $30 \%$ of all patients receiving treatment, experience a degree of GC insensitivity (9). Specifically, $4-10 \%$ of asthma patients (10), 30\% of rheumatoid arthritis patients (10), almost all chronic obstructive pulmonary disease (COPD) (10) and sepsis patients (5) and 10-30\% of
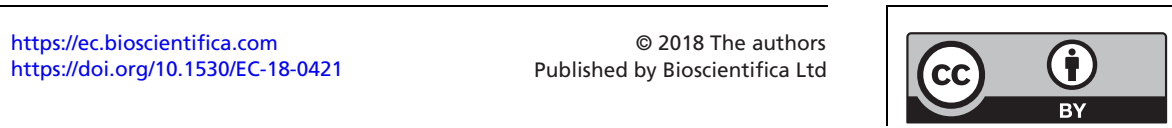
untreated acute lymphoblastic leukaemia (ALL) patients (11) experience varying degrees of GC insensitivity.

This stochastic response to GCs within disease groups (10), is compounded by inter-individual variation in patient sensitivity, as well as tissue-specific intraindividual differences in GC responsiveness (1). Thus, research is now focussed on developing diagnostic tools for determining GC sensitivity prior to treatment, for the use in personalized therapeutic regimens (12), which will likely assist in limiting adverse side effects and restrict the development of further GC insensitivity.

This review begins by briefly describing the types of GC resistance and then discusses reductions in the GR $\alpha$ pool in various pathological and psychological conditions, in terms of acquired GC resistance. Primary focus is given to disease- or treatment-associated reductions in the GR $\alpha$ pool, which drive the development of GC insensitivity, followed by the molecular mechanisms involved in mediating these reductions. Furthermore, current methods to restore GR $\alpha$ protein expression and improve GC sensitivity are briefly detailed. Lastly, a potential role for the conformation of GR $\alpha$ in receptor turnover is proposed, and a strategy using conformationally biased ligands is advocated to combat acquired GC resistance.

\section{GC resistance}

Following GC secretion into the bloodstream, GCs are transported to various tissues and cells and diffuse across the cell membrane where they bind and mediate their biological effects via their cognate receptor, the ligandactivated transcription factor, GR $\alpha$ (13). Upon ligand binding, the GR $\alpha$ undergoes a conformational change which allows for subsequent translocation to the nucleus (13). Here, the GC-bound GR $\alpha$ mediates the transrepression or transactivation of various GC-responsive genes $(13,14,15)$.

Central to the ability of GCs to combat inflammation is the requirement for a significant amount of functional GR $\alpha$ through which they may mediate their effects (16, 17). There are a multitude of factors which can regulate the functional pool of GR $\alpha$, either at the level of the functionality of the receptor and/or at the level of the GR $\alpha$ pool, thus ultimately contributing to GC resistance. In short, disruptions in $G R \alpha$ function $(1,7,18)$ are known to modulate, not necessarily independently of one another, the subcellular localization, ligand binding and transactivation ability of the receptor, and are regulated by, among others, increases in additional GR isoforms (GR $\beta$ and GR $\gamma$ ) due to alternative splicing events, inactivating GR $\alpha$ mutations, the inflammatory cytokine profile of the cellular microenvironment and mutations/ polymorphisms in the ERK pathway. However, rather than altered GR $\alpha$ function, the focal point of this review is reviewing the importance of the GR $\alpha$ pool, with regards to acquired GC resistance.

$\mathrm{GC}$ resistance is multi-faceted and has been extensively identified and studied in healthy and diseased states (9). Broadly speaking, GC resistance may be divided into two major groups: generalized (systemic/primary) or acquired (localized/secondary) GC resistance $(1,9)$. The generalized form of GC resistance falls beyond the scope of the current review, but for the interested reader is reviewed in several papers $(1,9,15,19)$. Essentially, these two groups of GC resistance are distinctively different in terms of the site of occurrence within a biological system, with acquired GC resistance often affecting specific tissues and/or cells while generalized GC resistance affects almost all tissues $(1,9)$. However, central to both types of GC resistance is perturbation of the GR $\alpha$ functional pool.

Acquired GC resistance is significantly more common in the general population and has been linked to a number of psychological and pathological conditions/ diseases. An apt description for this form of GC resistance is a 'consequence of a pathophysiological process' (5) affecting specific tissues/cell types (9). Furthermore, the clinical use of GCs, although effective initially, may lead to the development of acquired GC resistance thus posing a significant challenge for the long-term treatment of these conditions (9).

GC-resistant patients often require higher GC doses for prolonged periods of time in order to efficiently combat chronic inflammation, which likely leads to adverse side effects and may aggravate GC insensitivity (16). Thus, it is of importance for practitioners to be able to evaluate the GC responsiveness, of individual patients, to permit personalized GC treatment to obtain an optimal therapeutic outcome (12). Acquired resistance is more difficult to diagnose than generalized resistance, which generally displays a 'clinical picture' of GC resistance (1). In terms of generalized GC resistance, no single, standardized method for determining patient sensitivity to GC treatment exists (12), however, a range of endocrine (1) (e.g. cortisol awakening rise/response (CAR) or the 24-h urinary-free cortisol (UFC)) and biochemical methods (9) (dexamethasone suppression test (DST) or the more recent Dex/CRH suppression test) are employed to determine generalized GC resistance. In contrast, patients with or developing acquired GC resistance are mostly asymptomatic, thus, a range of in depth

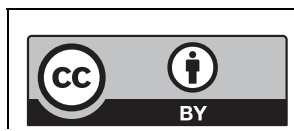

This work is licensed under a Creative Commons Attribution 4.0 International License. 
biochemical diagnostic approaches $(12,20,21)$ (e.g. BrdU incorporation lymphocyte steroid sensitivity assay (BLISS) and measuring the GC-responsive gene expression) are required to determine the GC responsiveness of specific tissues and/or cells. Although GC response can be determined, an increasing demand for more sensitive and specific tests remain, to avoid the unnecessary chronic GC use in treatment regimens (22).

\section{Reductions in the GR $\alpha$ pool and implications for acquired GC resistance}

In many, but certainly not all, stress-related, psychological and pathological conditions, reductions in the GR $\alpha$ pool have been noted (9) (Table 1). These disease-associated reductions in the GR $\alpha$ pool often produce GC-resistant forms within disease groups, which are exceptionally challenging to manage clinically (9). In addition to the disease-associated reductions in the GR $\alpha$ pool, generally mediated via increased circulating endogenous GCs, GC treatment-associated reductions in the GR $\alpha$ pool are well documented (Table 2). It is often difficult to distinguish between disease- and treatment-associated GR $\alpha$ turnover because withholding GC treatment from patients would not be ethical. Moreover, the treatment-associated effects on the GR $\alpha$ pool often exacerbate those that are diseaseassociated (23), further contributing to the development of acquired GC resistance.

\section{Disease-associated reductions in the GR $\alpha$ pool}

There is a wealth of evidence associating stress, psychological and pathological conditions, with the development of an acquired GC resistance, through reductions in the GR $\alpha$ pool (Table 1).

Specifically, in terms of stress, the modulation of the GR $\alpha$ pool is fundamentally dependent on the duration of the stressor, the environment in which the stress occurs, and the individual's sensitivity to stress $(24,25$, $26,27,28,29,30,31,32,33,34,35,36,37,38,39,40$, $41,42,43)$. Various stressors ranging from pre- or postnatal to physical and psychological stress, in a number of human and rodent studies, encompassing various different tissues and cells, result in significant reductions in the GR $\alpha$ mRNA and/or protein pool (Table 1). These reductions are generally, but not always (26), correlated with stress-induced increases in circulating endogenous GCs $(24,25)$. Whilst GC-mediated receptor turnover is thought to be an adaptive mechanism employed by the cell to protect against the damaging effects of unrelenting stress, this reduction in the GR $\alpha$ pool has implications in GC sensitivity, often leading to a blunted GC response (42). Jung et al. (38), supported by Quan et al. (43), noted reductions in the GR $\alpha$ mRNA, and protein pool following repeated social defeat in rodent models, and importantly correlated these reductions to a consequent diminished GC sensitivity. In addition to encouraging the development of GC resistance, certain chronic physical, psychological and/or pre- or post-natal stressors can also increase susceptibility to severe psychological or pathological conditions $(44,45)$. An example is a recent study by Han et al. (44) where stress-induced hypercortisolemia mediated a decrease in the GR $\alpha$ protein pool in the hypothalamus of mice, which subsequently increased their susceptibility to psychological disorders (e.g. depression).

In many psychological disorders, including depression and schizophrenia, a large cohort of patients, but not all $(46,47)$, display consistent biological findings $(48,49)$, namely an increase in inflammation and hyperactivity of the HPA, which drives hypercortisolemia, with consequences for the GR $\alpha$ pool in peripheral tissues (50). Whilst it must be noted that vast heterogeneity in GR $\alpha$ expression exists in patients with psychological conditions $(48,49,50,51,52,53,54,55,56,57,58$, $59)$, the current review focuses on conditions/disorders which have been explicitly linked to reductions in the GR $\alpha$ pool (Table 1). Specifically, a number of studies have demonstrated a reduction in the GR $\alpha$ mRNA pool in patients suffering from major depression (MD) $(52,53$, 58), schizophrenia (58), bipolar disorder (58) and posttraumatic stress disorder $(54,56,57,59)$ in various tissues of the brain (e.g. the hippocampus and prefrontal cortex) as well as in peripheral blood mononuclear cells (52, 53, 58). Furthermore, in patients suffering from generalized anxiety disorder, a negative correlation was made between circulating GC concentrations and the GR $\alpha$ mRNA pool, which was subsequently shown to result in diminished GC sensitivity (55).

In terms of pathological conditions, it is difficult to tease apart whether modulations in the GR $\alpha$ pool are a pathological consequence of the disease, as in the case of many psychological disorders, or as a result of prolonged GC treatment, which many of these patients require (60). Nevertheless, this review highlights cases in which reductions in the GR $\alpha$ pool are noted in autoimmune or inflammatory-linked conditions, cancers and infection or other conditions, attempting to limit it to cases in which patients were not receiving treatment (Table 1).

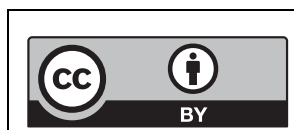

This work is licensed under a Creative Commons Attribution 4.0 International License. 


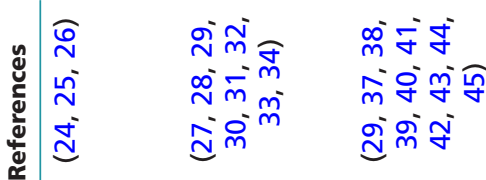

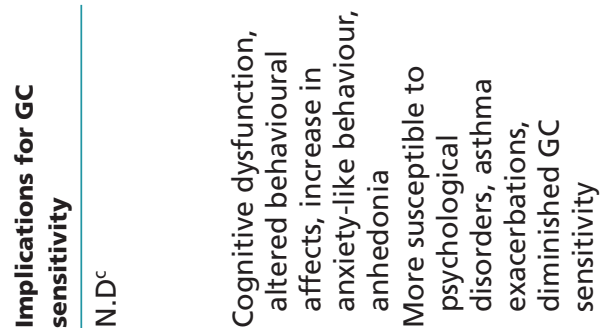

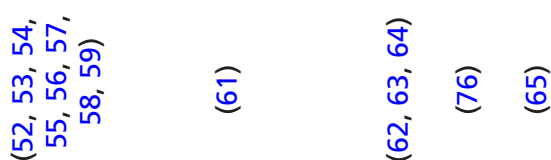

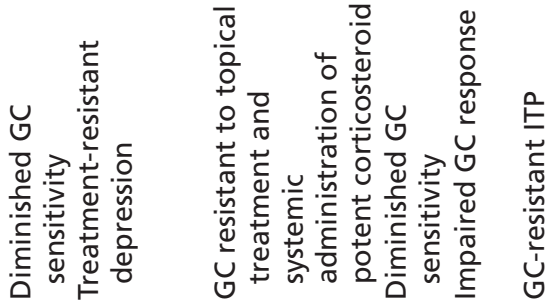

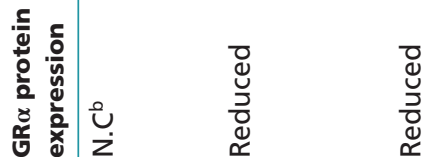

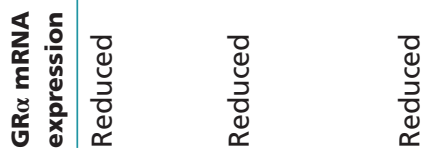

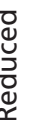

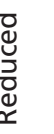

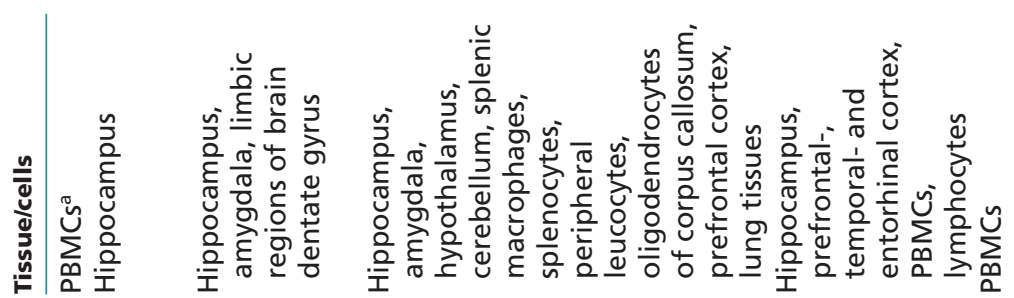

$\sum_{0}^{\bigcup} \sum_{0}^{\bigcup} \sum_{0}^{\bigcup}$
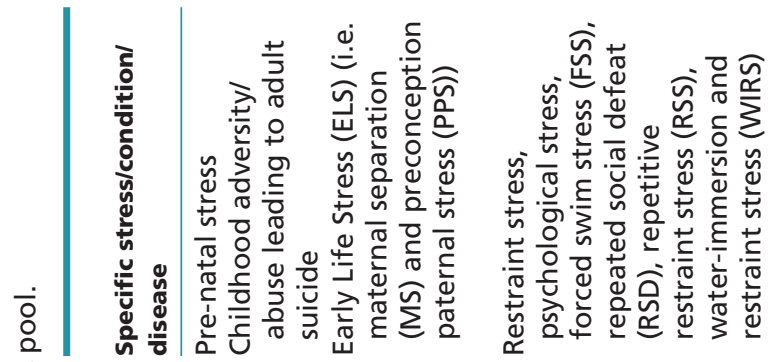

总

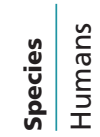

$\stackrel{0}{0}$
$\stackrel{0}{0}$
$\stackrel{0}{0}$
$\stackrel{0}{x}$

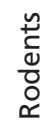

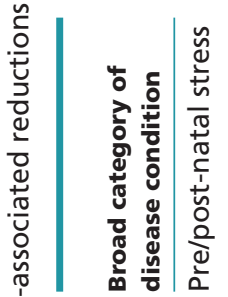

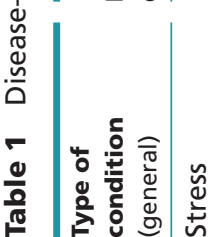

https://ec.bioscientifica.com

https://doi.org/10.1530/EC-18-0421

(๑) 2018 The authors Published by Bioscientifica Ltd
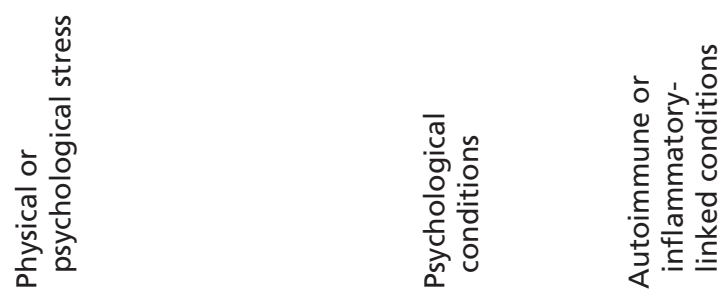

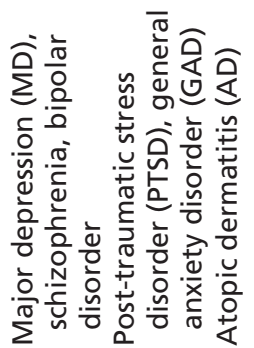

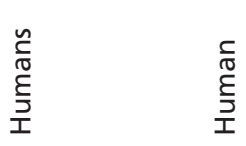

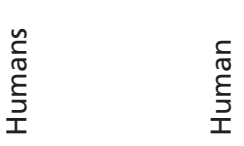
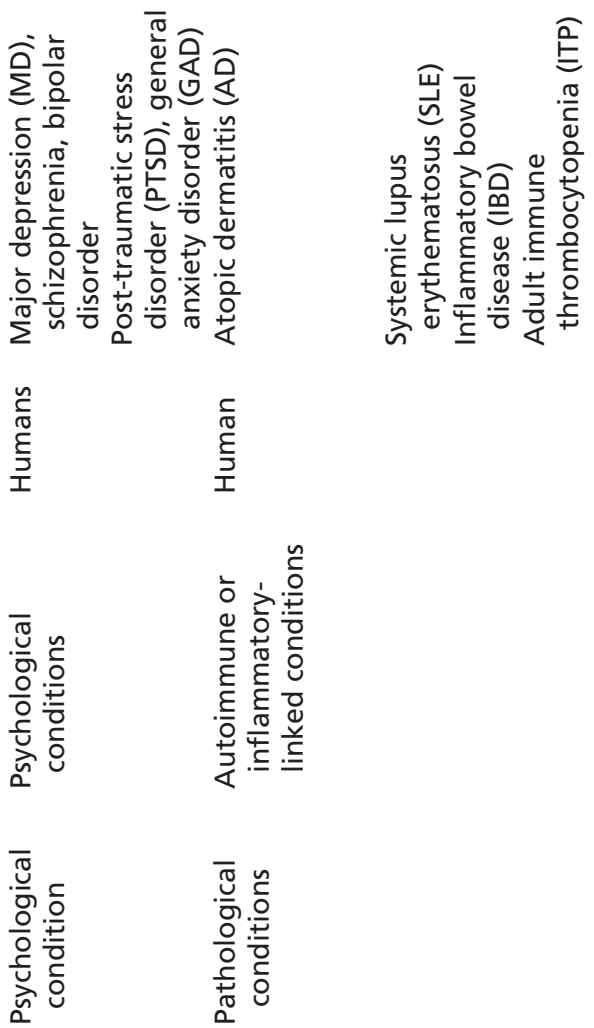

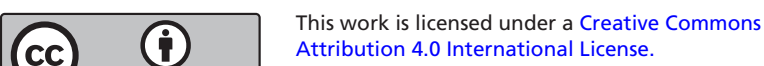




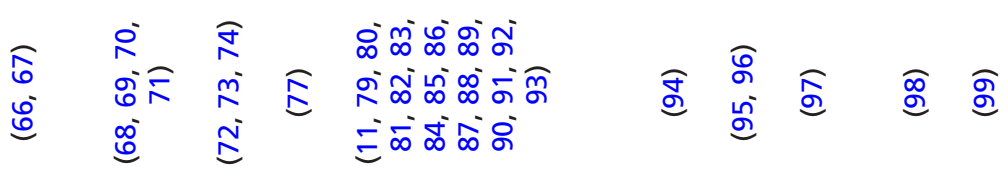

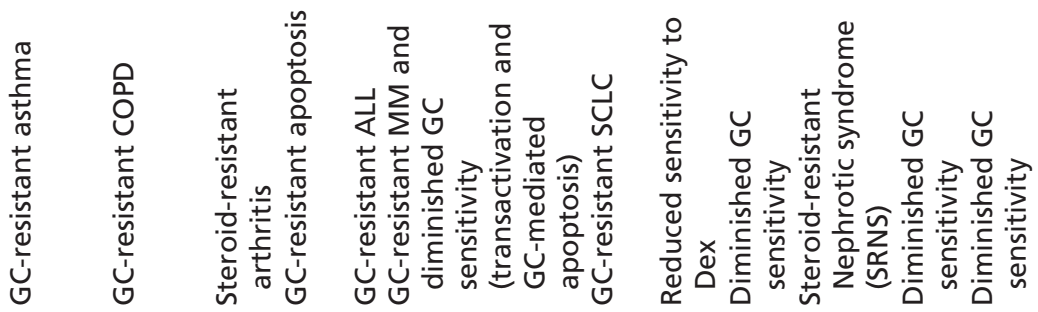

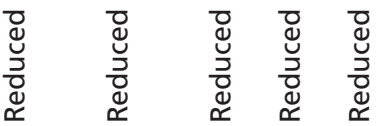

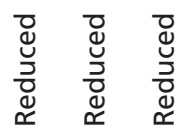

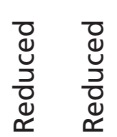

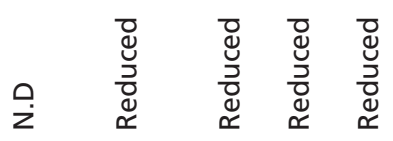

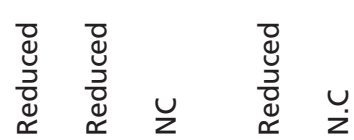

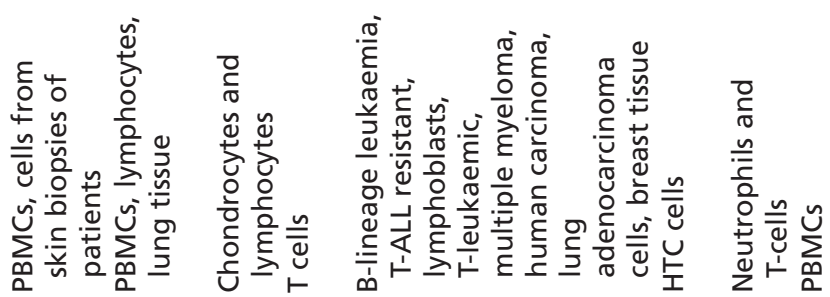

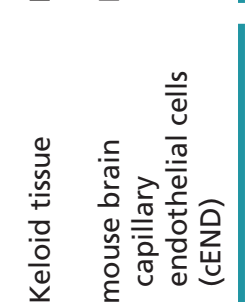

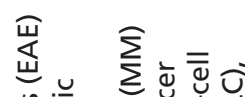

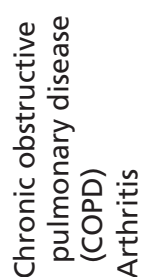

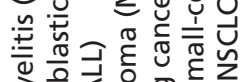

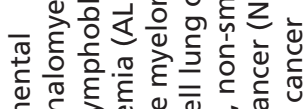

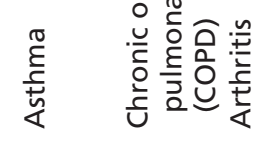

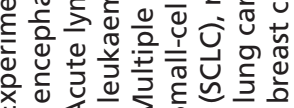

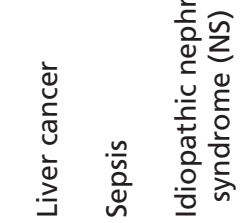

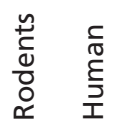

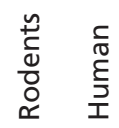

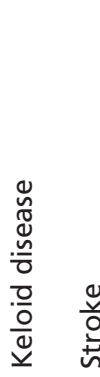

ปัঠ

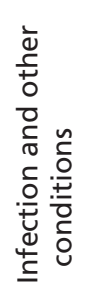




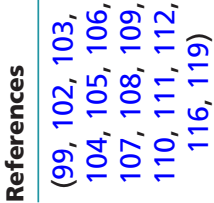

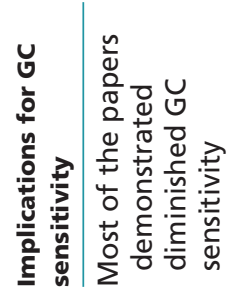

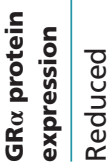

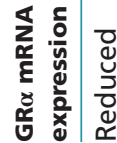

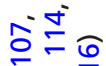

高望望

8̊ㅇ-$$
\text { ( }
$$

芒

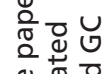

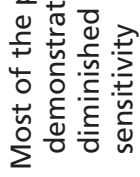

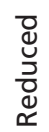

ত্ّু
$\stackrel{\Xi}{E}$

$\stackrel{\circ}{2}$

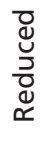

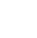

in

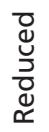

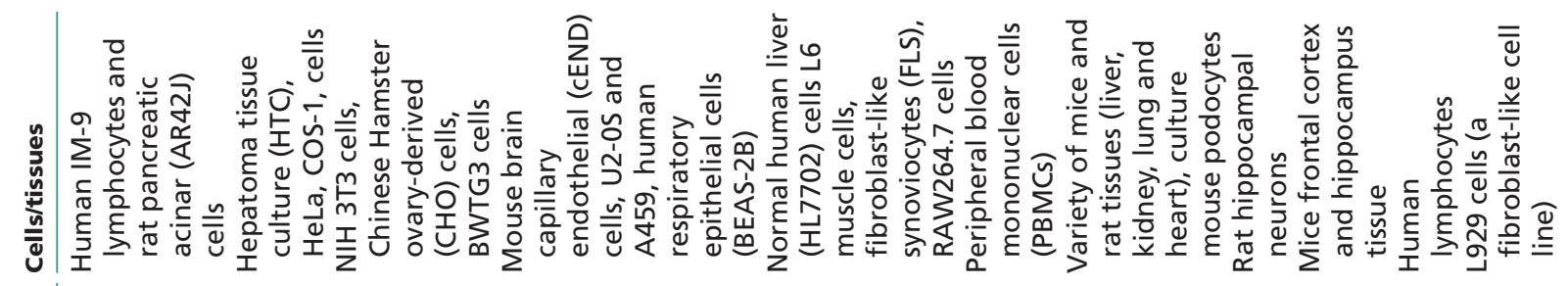

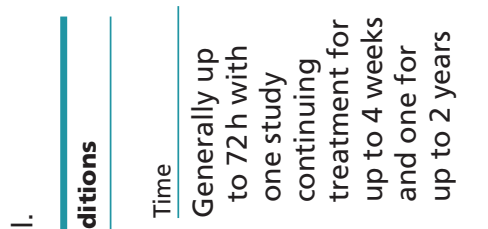

这

요

ㅇำ

๕ั

के

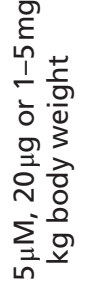

운

$\sum_{\underline{\Xi}}$

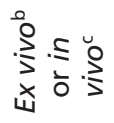

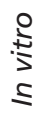

作

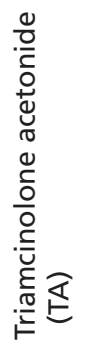

https://ec.bioscientifica.com 


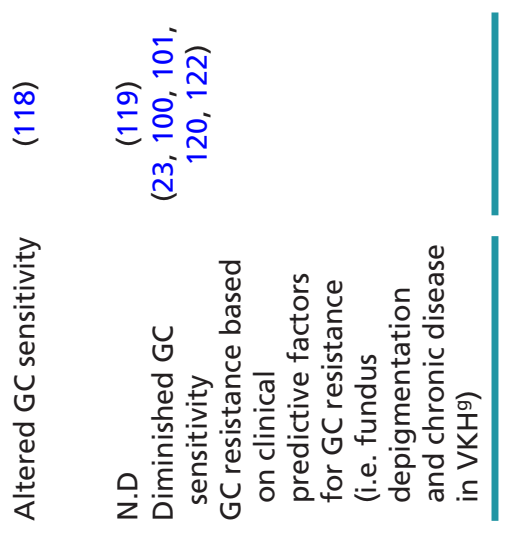

之⿺ 丶万

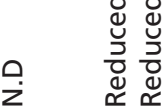
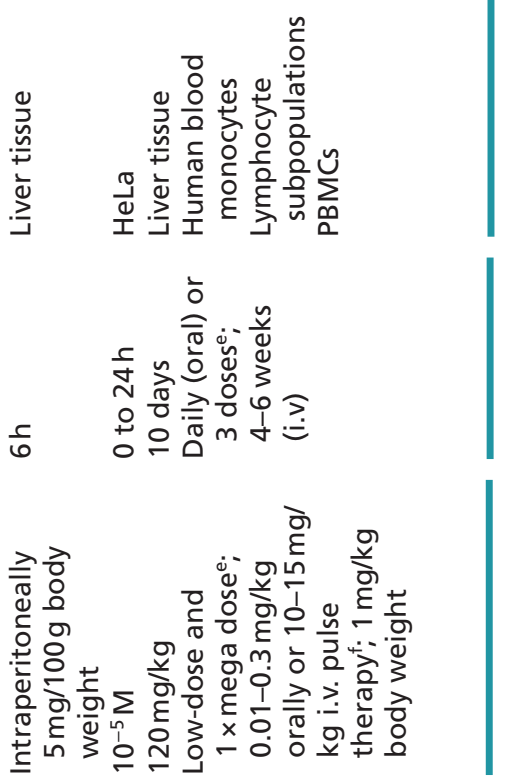

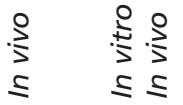

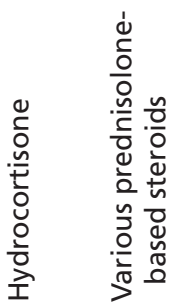

https://ec.bioscientifica.com https://doi.org/10.1530/EC-18-0421
In autoimmune and inflammatory-linked conditions, a significant correlation between disease-associated reductions in the GR $\alpha$ pool and GC resistance has been demonstrated for atopic dermatitis (AD) (61), systemic lupus erythematosus (SLE) $(62,63,64)$, adult immune thrombocytopenia (65) (ITP), steroid-resistant Type II asthma $(66,67)$, chronic obstructive pulmonary disease $(68,69,70,71)$ and osteoarthritis in humans $(72,73,74)$. However, it has been suggested that the level of the GR $\alpha$ pool is not the primary determinant for GC sensitivity in all inflammatory-linked conditions as in the resistant form of irritable bowel disease $(75,76)$ and rheumatoid arthritis (73), for example, a reduction in the GR $\alpha$ pool does not always correlate with GC resistance, nevertheless a partial role for the GR $\alpha$ pool likely exists. Furthermore, in a rodent model, T-cells obtained from mice with experimental autoimmune encephalomyelitis, have a reduced GR $\alpha$ mRNA pool, which was linked to diminished GC sensitivity, in terms of GC-resistant apoptosis (77).

GCs are a primary therapeutic choice in cancer for either their pro-apoptotic effects or their use as an adjuvant therapy, in combination with chemotherapeutic agents, to reduce symptoms such as inflammation, allergic reactions, pain and nausea, which may also be caused by the tumour itself (78). However, both the type of cancer cell as well as the level of the GR $\alpha$ pool of certain cancer cells are thought to play a significant role in mediating the response to GC treatment $(78,79,80,81,82)$. It is fairly well documented that high GR $\alpha$ expression is associated with a good response to GC treatment in lung cancer; however, drastic reductions in the GR $\alpha$ pool, thought, in part, to be a pathological consequence of the tumorigenic process may lead to GC insensitivity. Specifically, a number of authors have detailed that a reduction in the GR $\alpha$ pool is negatively correlated to GC response $(78,79,80,81,82)$. For example, in acute lymphoblastic leukaemia (ALL) (83, $84,85,86)$, multiple myeloma $(\mathrm{MM})(87,88,89,90,91)$, lung cancer (i.e. small-cell lung cancer (SCLC) and nonsmall-cell lung cancer (NSCLC)) $(78,79,80,81,82)$ and breast cancer $(92,93)$, reductions in the GR $\alpha$ pool, have been associated with treatment-resistant forms of these cancers and/or diminished GC sensitivity. Furthermore, Vanderbilt et al. (94) established that the GC response in a rat hepatoma cell line was modulated in accordance to the level of the GR $\alpha$ pool.

Apart from autoimmune and inflammatory-linked diseases and certain cancers, disease-associated reductions in the GR $\alpha$ pool have been documented in conditions such as sepsis $(95,96)$, nephrotic syndrome (NS) (97), keloid disease (98) and stroke (99). Although these reductions in

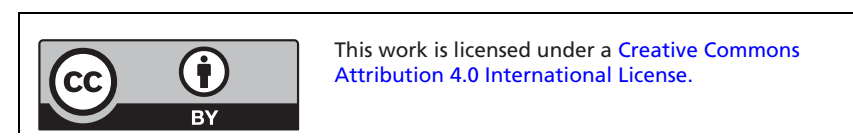


receptor expression were generally negatively correlated to GC sensitivity, in sepsis, the association between the GR $\alpha$ pool and the GC response is, however, highly variable (5). In children with NS, the level of the GR $\alpha$ protein pool was assessed before exogenous GC treatment in two patient groups, namely the steroid-sensitive (SSNS) and the steroid-resistant (SRNS) groups (97). Patients from the SRNS group were reported to have reductions in the cellular GR $\alpha$ protein pool, which Hammad et al. (97) postulated may be one of the pathophysiological mechanisms of acquired GC resistance in these children. As with NS (97), patients with keloid disease may be separated into two groups, namely non-responders (nRPs) or responders (RPs) (98). Before receiving GC therapy, tissue isolated from keloid scars from nRPs displayed reductions in the GR $\alpha$ pool, both mRNA and protein, which was associated with decreased GC sensitivity following treatment (98). Lastly, in an in vitro model of hypoxia (used to mimic stroke events), endothelial cells isolated from mice brains, following $\mathrm{O}_{2}$ /glucose deprivation had significant reductions in their $\mathrm{GR} \alpha$ protein pool, relative to normoxic cells, which was proposed to be the cause of a decrease in subsequent GC sensitivity (99).

It is clear that chronic stress and certain psychological and pathological conditions drive disease-associated reductions in the GR $\alpha$ pool, often independently of exogenous GC treatment. More importantly, in many cases, these reductions in the GR $\alpha$ pool have been directly correlated to an increase in GC insensitivity and resistant forms of these diseases.

\section{GC treatment-associated reductions in the GR $\alpha$ pool}

It is often difficult to discriminate between disease- and treatment-associated reductions in the GR $\alpha$ pool (60). However, some clinical studies have demonstrated treatment-associated reductions in the GR $\alpha$ pool independent of disease-associated reductions $(100,101)$. Using various in vitro, in vivo and ex vivo human and/or rodent models, a number of studies have demonstrated that exogenous GC treatment, e.g. with dexamethasone (Dex), results in significant dose- and time-dependent reductions in the GR $\alpha$ pool with implications for GC sensitivity (Table 2).

Specifically, in vitro Dex treatment led to timedependent reductions in the GR $\alpha$ mRNA and/or protein pool, of between 50 and $90 \%(60,99,102,103,104,105$, 106, 107, 108, 109, 110, 111, 112, 113, 114, 115, 116). Interestingly, Dex treatment of HeLa cells conducted for 2 years, led to reductions in the GR $\alpha$ mRNA and protein pool to below detectable levels (103). Moreover, in most of these studies, where both the GR mRNA and protein pool was assessed, it would appear that the Dex-mediated reductions in the GR $\alpha$ protein pool were generally greater than that observed for the GR $\alpha$ mRNA pool. In a study by Bellingham et al. (112), the rapid Dex-mediated reduction in GR $\alpha$ protein expression was maintained even after 4 weeks, while GR $\alpha$ mRNA expression displayed a 'biphasic pattern', with an initial decrease followed by rise in receptor mRNA expression and a subsequent decline, which was attributed to ligand-induced transcriptional, post-transcriptional and translational regulation in mediating receptor mRNA expression, which was not reflected at the protein level (112). A number of studies using ex vivo and in vivo models mirror results of Dexmediated reductions in the GR $\alpha$ mRNA and/or protein pool obtained in cell lines. In a variety of mouse tissues and rat liver tissue, prolonged treatment with Dex led to significant reductions in the GR $\alpha$ pool $(60,102,107,113$, $114,115,116)$, which in some cases was associated with diminished GC sensitivity $(102,116)$.

Importantly, several in vitro, ex vivo and in vivo studies have demonstrated that GC sensitivity is compromised following prolonged Dex treatment, as a result of a significant reduction in the GR $\alpha$ pool $(60,99,102,103$, 104, 105, 106, 107, 108, 109, 110, 111, 112, 113, 114, 115, 116), highlighting how long-term GC therapy contributes to the development of acquired GC resistance. In addition to Dex, Table 2 also summarizes the reductions in the GR $\alpha$ mRNA and/or protein pool mediated by other exogenous GCs $(23,101,117,118,119,120,121,122)$, such as hydrocortisone (118).

Taken together, both disease and/or exogenous GC treatment drive reductions in the GR $\alpha$ pool and development of acquired GC resistance, a major clinical challenge. With the burden of resistance to GC treatment mounting, it is of utmost importance to understand the molecular mechanisms involved in ligand-induced GR $\alpha$ turnover.

\section{Molecular mechanisms of GC-mediated reductions in GR pool}

To date, a number of GC-mediated molecular mechanisms employed by the cell have been identified to tightly regulate the GR $\alpha$ pool (Table 3).

The regulation of the GR $\alpha$ pool may be described using a simple 'push' vs 'pull' mechanism where, when in a dynamic state of equilibrium and unperturbed,

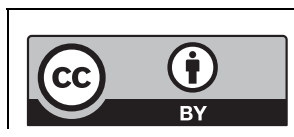

This work is licensed under a Creative Commons Attribution 4.0 International License. 
the synthesis of GR $\alpha$ is roughly equivalent to receptor turnover and the level of the GR $\alpha$ pool remains constant (Fig. 1). The 'push' is governed by two processes namely transcription and translation while the 'pull' is defined by proteasomal degradation, specifically via the ubiquitinproteasome pathway (UPS). One can assume that perturbations in the equilibrium state of GR $\alpha$ regulation will most likely result in alterations in the GR $\alpha$ pool. One of the ways in which the equilibrium of this dynamic state may be perturbed is via an increase in circulating GCs, either endogenous (i.e. disease-associated increases; Table 1) or exogenous (due to prolonged treatment; Table 2), which subsequently induces GC-mediated GR $\alpha$ turnover.

GC-mediated regulation of the GR $\alpha$ pool is complex and involves multiple layers of epigenetic, transcriptional, post-transcriptional and post-translational regulation (9, 15). At each level of regulation, the molecular mechanisms function in a highly specific manner to stabilize or destabilize the GR $\alpha$, which contributes to the complexity of the finely tuned GC/GR $\alpha$ signalling pathway, with receptor destabilization potentially advancing acquired GC resistance. This review focuses specifically on the molecular mechanisms, which function to reduce the $\mathrm{GR} \alpha$ mRNA and protein pool in a ligand-dependent manner, however, ligand-independent regulation has been described $(1,9,15)$.

\section{$\mathrm{GR} \propto \mathrm{mRNA}$ regulation}

\section{Epigenetic regulation}

DNA methylation of the GR $\alpha$ (NCR31) promoter (123) has been identified as one of the major mechanisms involved in disease-associated acquired GC resistance across species $(24,25,30,32,33,42,55,81,92)$ and has been positively correlated with an increase in circulating GCs (42). GC-mediated increases in DNA methylation of the GR $\alpha$ promoter generally, but not always (47), lead to a reduction in the GR $\alpha$ mRNA pool and possibly a corresponding reduction in the GR $\alpha$ protein pool (Table 3).

A specific exonic sequence in the rat GR $\alpha$ gene has been identified as a region that undergoes substantial DNA methylation following stressful events $(30,32,42)$.
Specifically, increased DNA methylation at the exon $1_{7}$ promoter, within the GR $\alpha$ promoter, was shown to mediate a reduction in the GR $\alpha$ mRNA pool $(30,32$, 42), with Mifsud et al. (42), demonstrating up to a $75 \%$ reduction in the GR $\alpha$ mRNA pool in dentate gyrus neurons of male Wistar rats. In mice, methylation of the same exon $1_{7}$ promoter led to a significant reduction in the GR $\alpha$ protein pool (33). Additionally, human studies have demonstrated that DNA methylation of the GR $\alpha$ gene, specifically at exon $1_{\mathrm{F}}$, exon $1_{\mathrm{D}}$, exon $1_{\mathrm{B}}$, exon $1_{\mathrm{H}}$ and exon $1_{C}$, resulted in reductions in the GR $\alpha$ mRNA pool $(24,25,55,81,92)$. DNA methylation of the exon $1_{\mathrm{F}}$ promoter led to reductions in the GR $\alpha$ mRNA pool in tissues/cells from victims with a history of abuse (25) and patients with generalized anxiety disorder (55), with the latter being correlated to diminished GC sensitivity (55). Similarly, for exon $1_{\mathrm{B}}$, exon $1_{\mathrm{C}}$ and exon $1_{\mathrm{H}}$, an increase in the methylation status at these sites was associated with a decrease in the GR $\alpha$ mRNA pool, in breast cancer tissue (92) and the hippocampi of suicide completers (24). Furthermore, Kay et al. (81) showed that a 6\% increase in $\mathrm{GR} \alpha$ methylation resulted in a reduction in the receptor protein pool by up to $50 \%$, in human small-cell lung cancer cells. Collectively, these studies highlight a role for DNA methylation in GC-mediated reductions in the GR $\alpha$ pool and demonstrate that this epigenetic mechanism is likely to contribute to the development of acquired GC resistance.

\section{Transcriptional regulation}

The GR $\alpha$ promoter has a negative glucocorticoid response element (nGRE) $(107,124)$. GC-mediated inhibition of transcription initiation of the GR $\alpha$ gene was shown to be the primary mechanism for up to a $90 \%$ reduction in the nascent GR $\alpha$ mRNA pool (107). Specifically occurring through a long-range interaction between the GC-bound GR $\alpha$, at a nGRE present in exon 6, and a NCOR1 repression complex, which is assembled at the transcription start site of the gene (107). The ability of the GC-bound GR $\alpha$ to regulate its own transcription was neither species nor tissue specific (107). Whilst Ramamoorthy et al. (107)

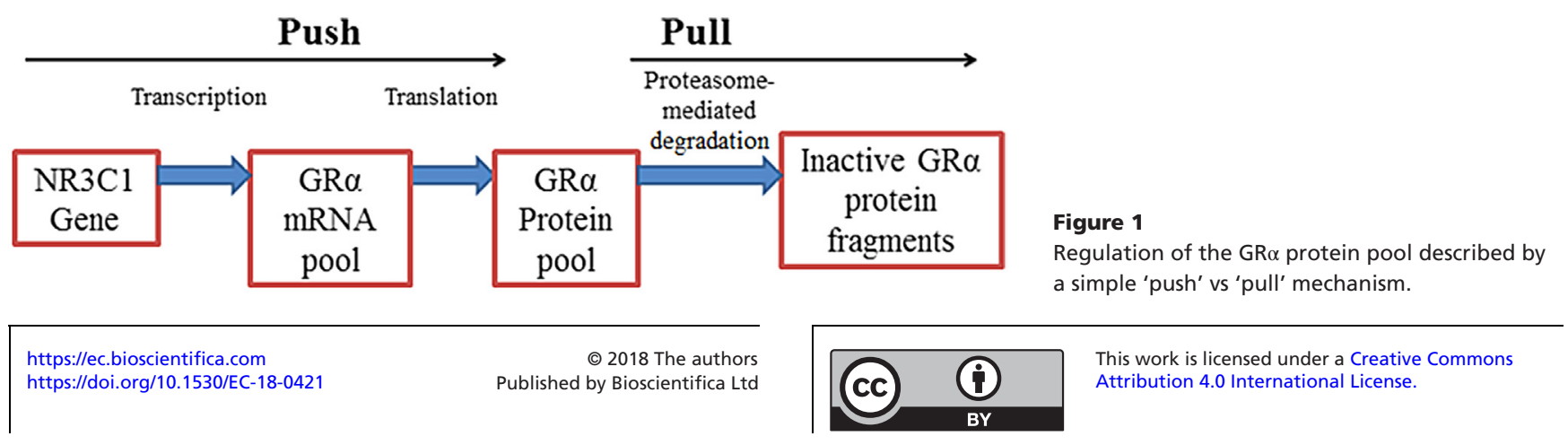


Table 3 GC-mediated molecular mechanisms involved in reducing GR $\alpha$ expression.

\begin{tabular}{|c|c|c|c|c|c|}
\hline Level of regulation & Molecular mechanism & Species & $\begin{array}{l}\text { GR } \alpha \text { mRNA } \\
\text { expression }\end{array}$ & $\begin{array}{l}\text { GR } \alpha \text { protein } \\
\text { expression }\end{array}$ & References \\
\hline Epigenetic & DNA methylation of GR $\alpha$ gene & & & & \\
\hline \multirow[t]{2}{*}{ Transcriptional } & GR $\alpha$ gene regulation via GRE $^{a}$ & & & & \\
\hline & $\begin{array}{l}\text { - Present in exon } 6 \\
\text { miRNA }\end{array}$ & Human & Reduced & N.D & $(107)$ \\
\hline Post-transcriptional & $\begin{array}{l}\text { Rodents: miR-96, miR-101a, } \\
\text { miR-142-3p, miR-433, miR-29b, } \\
\text { miR-340-5p, miR-18 and miR-124a } \\
\text { Humans: miR-124, miR-130b and } \\
\text { miR-142-3p }\end{array}$ & Rodent & Reduced & Reduced & $(38,40,42,127,128,129)$ \\
\hline \multirow{5}{*}{ Post-translational } & $\begin{array}{l}\text { - Rodents: } \\
\circ \text { Multiple mouse mutations } \\
\text { (Ser212, Ser220 and Ser234) } \\
\circ \text { Hyper-phosphorylation at Ser412 }\end{array}$ & Mouse & $N \cdot A^{c}$ & Decreased & $(136,137)$ \\
\hline & $\begin{array}{l}\text { - Humans: hyper-phosphorylation at } \\
\text { Ser211, Ser226 and Ser404 } \\
\text { Ubiquitination }\end{array}$ & Human & N.A & Decreased & $(135,136)$ \\
\hline & $\begin{array}{l}\text { - } \text { Rodents: K426 } \\
\text { - Humans: K419 }\end{array}$ & $\begin{array}{l}\text { Mouse } \\
\text { Human }\end{array}$ & $\begin{array}{l}\text { N.A } \\
\text { N.A }\end{array}$ & $\begin{array}{l}\text { Decreased } \\
\text { Decreased }\end{array}$ & $\begin{array}{c}(99,104,105,139,142) \\
(105,141,143,144,145,146)\end{array}$ \\
\hline & $\begin{array}{l}\text { Proteasome degradation (i.e. use of } \\
\text { proteasome inhibitors) }\end{array}$ & & & & \\
\hline & $\begin{array}{l}\text { - Rodents: MG132 or bortezomib (BZ) } \\
\text { - Humans: MG132 or BZ } \\
\text { Sumoylation } \\
\text { - Specific site unknown }\end{array}$ & $\begin{array}{l}\text { Mouse } \\
\text { Human } \\
\text { Human }\end{array}$ & $\begin{array}{l}\text { N.A } \\
\text { N.A }\end{array}$ & $\begin{array}{l}\text { Decreased } \\
\text { Decreased } \\
\text { Decreased }\end{array}$ & $\begin{array}{c}(99,104,105,139,142) \\
(105,141,143,144,145,146) \\
(152)\end{array}$ \\
\hline
\end{tabular}

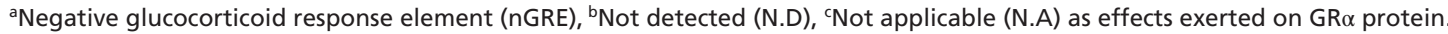

convincingly demonstrated that the GC-mediated autoregulatory loop to repress the GR $\alpha$ gene occurs via an nGRE in the GR $\alpha$ gene promoter; it appears to be the only study to do so.

\section{Post-transcriptional regulation}

Unlike transcriptional regulation of the GR $\alpha$ gene that modulates nascent receptor mRNA expression, posttranscriptional regulation involves the destabilization of mature receptor mRNA via the presence of adenylate uridylate (AU)-rich elements present in the 3 '-untranslated region (UTR) of the GR $\alpha$ mRNA transcript, which may ultimately affect receptor protein expression, presenting another level of regulation for fine-tuning GR $\alpha$ expression (125). One of the ways in which this can occur is through the regulatory role of miRNAs, which bind to 3 '-UTR of GR mRNA (22). These miRNAs are a family of small noncoding RNAs, which primarily prevent efficient translation of mRNA transcripts but can also induce degradation of these transcripts (126).

$\begin{array}{lr}\text { https://ec.bioscientifica.com } & \text { ○ } 2018 \text { The authors } \\ \text { https://doi.org/10.1530/EC-18-0421 } & \text { Published by Bioscientifica Ltd }\end{array}$

The ability of miRNAs to regulate the GR $\alpha$ mRNA pool has been shown to be GC mediated and has been implicated in acquired GC resistance (Table 3). Vandevyver et al. (15) reviews most, but not all (38), of the miRNA target sites in the GR $\alpha$ mRNA transcript; however, the current review will focus only on miRNAs which reduce the GR $\alpha$ pool. Four miRNAs, namely miR-96, miR-101a, miR-142-3p and miR-433, drive reductions in the GR $\alpha$ mRNA pool by up to $40 \%$ in mice (127). Additionally, social stress in mice (38) and acute stress in rats (42), resulted in an increase in miR-29b and miR-340-5p and miR-124a expression, respectively, which was associated with a significant reduction in the GR $\alpha$ mRNA pool. Reductions of the GR $\alpha$ protein pool in rats not necessarily reflected at the mRNA level have also been noted as a result of an increase in miR-18 (128, 129) and miR-124a (40). In humans, a reduction in the GR $\alpha$ pool (both mRNA and protein) was noted following a GC-mediated increase in miR-124, in ALL cells (130) and in T-cells of sepsis patients (95). Moreover, Tessel et al. (89) demonstrated that overexpression of

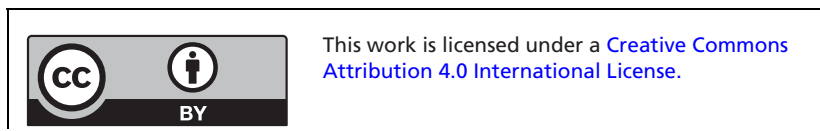


miR-130b mediated a reduction in the GR $\alpha$ protein pool in human MM cell lines; however, knockdown of this miR-130b did not alter GR $\alpha$ protein levels and whilst experiments were conducted in the presence of Dex, it is not clear whether GC's directly mediated the expression of miR-130b (89). Moreover, an increase in miR-142-3p expression and consequent decrease in the GR $\alpha$ protein pool has been noted in GC-resistant ALL patients (84). Unfortunately, in many of these studies, it is unclear whether up to $80 \%$ increase in miRNA expression (38) is directly mediated via an increase in circulating GCs; however, from other studies, one could postulate that a positive correlation between the two exists.

\section{$\mathrm{GR} \alpha$ protein regulation}

\section{Post-translational regulation}

Additionally, the GR $\alpha$ protein is also subjected to GC-mediated regulation in the form of post-translational modifications (PTMs). The nature and degree of these PTMs modulates both GR $\alpha$ function and pool, impacting $\mathrm{GC}$ responsiveness in selective tissues, and in some cases, contributes to an acquired GC resistance (15). In this review, we focus on GC-mediated PTMs, which drive reductions in the $\mathrm{GR} \alpha$ pool via the proteasome. The effects of PTMs on GR $\alpha$ function are reviewed in several papers $(7,13,15,131,132,133,134)$.

For GR $\alpha$, the most widely studied and first PTM identified was phosphorylation (15). Since the initial discovery, additional GR $\alpha$ phosphorylation sites have been identified (Fig. 2). Basal GR $\alpha$ phosphorylation may occur in a ligand-independent manner $(135,136)$, however, hyperphosphorylation at several of these sites is GC-mediated $(135,136)$ and modulates $\mathrm{GR} \alpha$ function as well as the receptor pool $(15,135,136)$. Moreover, various kinases (e.g. p38, ERK, JNK, CDKs and GSK3 $\beta$ (136)) responsible for the phosphorylation of these sites have been described (15).
Webster et al. (137) demonstrated that multiple point mutations (i.e. at S212, S220 and S234) in the mouse GR $\alpha$, which correlate to S203, S211 and S226 of the human GR $\alpha$ (15), respectively, restricted GC-mediated GR $\alpha$ protein turnover. GC-mediated hyper-phosphorylation of the human GR $\alpha$ at S211, S226 (135) and S404 (136) (or Ser412 in mice (136)) led to reductions in the GR $\alpha$ protein pool. Moreover, inhibiting the GC-mediated hyper-phosphorylation at S404, through the use of a mutant or a kinase inhibitor, resulted in a significant increase in GR $\alpha$ protein stability (136). To our knowledge, these are the only sites $(135,136,137)$, which directly demonstrate the ability of GC-mediated phosphorylation of the human $\mathrm{GR} \alpha(135,136)$ and the mouse GR $\alpha(137)$ to affect the GR $\alpha$ pool.

It was postulated, but not demonstrated experimentally, that, apart from the inability to be phosphorylated, the phospho-deficient GR $\alpha$ mutants (137, 138), could not be ubiquitinated. Protein ubiquitination is preceded by phosphorylation and is a fundamental requirement for protein degradation via the proteasome; however, GR $\alpha$ ubiquitination is not well documented with only a handful of papers specifically demonstrating GC-mediated GR $\alpha$ ubiquitination $(99,104,105,139,140,141,142,143,144$, $145,146)$. Moreover, the idea that ubiquitination of GR $\alpha$ increases following GC treatment seems to be controversial, with one paper demonstrating a Dex-mediated increase in GR $\alpha$ ubiquitination (140) while others noted a Dexinduced reduction in GR $\alpha$ ubiquitination in the presence of a proteasome inhibitor $(105,142)$. It seems necessary for further research to be conducted in this specific area of GC/GR $\alpha$ signalling. To date, only a single ubiquitination site for GR $\alpha$ that occurs within the PEST degradation motif at Lys426 in mice and Lys419 in humans has been identified, with mutations at these sites restoring the GR $\alpha$ protein pool, by restricting GR $\alpha$ turnover via the

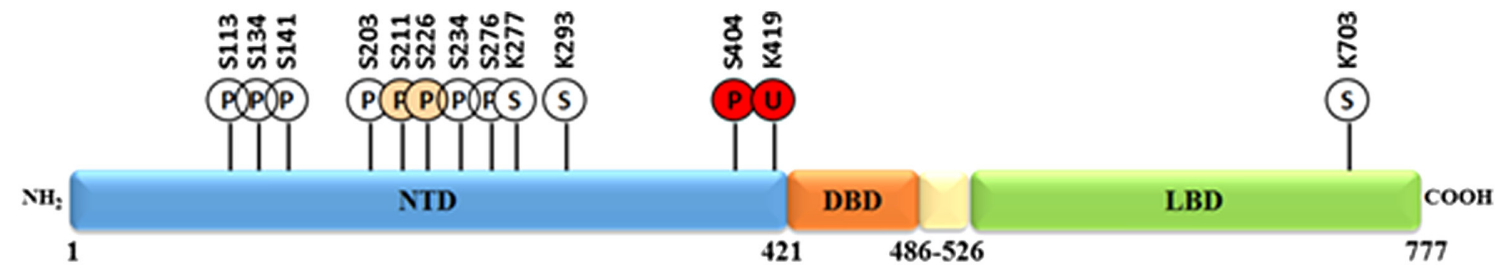

Figure 2

Post-translational modification sites of human GR $\alpha$ with focus on phosphorylation, ubiquitination and sumoylation. The human GR $\alpha$ protein consists of 777 amino acids and undergoes PTMS at numerous sites. Moreover, many of these PTM sites are contained within the N-terminal domain (NTD) (amino acids 1 to 421) of the receptor, with two present in close proximity to the DNA-binding domain (DBD) (amino acids 421 to 486 ). Specifically, phosphorylation (P) occurs at serine (e.g. S211, S226 and S404) residues, whilst ubiquitination (U) and sumoylation (S) occurs at lysine residues (i.e. K419 and K277, K293 and K703, respectively). Unlike the others, the K703 sumoylation site occurs within the ligand-binding domain (LBD) of the receptor (amino acids 526 to 777). Moreover, PTMs at these sites are known to modulate GR $\alpha$ function (white) or protein expression (red) and in some cases affect both receptor function and protein expression (pink).

https://ec.bioscientifica.com

https://doi.org/10.1530/EC-18-0421 (c) 2018 The authors Published by Bioscientifica Ltd

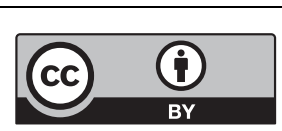

This work is licensed under a Creative Commons Attribution 4.0 International License. 
proteasome $(104,105)$. Nevertheless, several studies have through the use of proteasome inhibitors, definitively implicated the ubiquitin-proteasome system (UPS) in the control GR $\alpha$ degradation rates, ultimately contributing to the stringent regulation of the GR $\alpha$ protein pool $(99,102$, $104,105,139,142,145,147)$.

Similarly to ubiquitination, sumoylation is a dynamic, reversible process, which involves a multi-step, enzymecatalysed reaction to mediate the covalent attachment of the SUMO protein (e.g. SUMO-1, SUMO-2/3) to the protein of interest (148). Sumoylation of the GR $\alpha$ is known to modulate $G R \alpha$ function $(131,149,150,151,152)$ and, less frequently, promote reductions in the GR $\alpha$ pool (152). Specifically, Le Drean et al. (152) demonstrated that overexpression of SUMO-1 aids Dex-mediated receptor downregulation; however, this paper is the only paper to describe the potential of sumoylation to regulate GR $\alpha$ protein expression.

\section{Enzymes of the UPS that mediate GR $\alpha$ protein turnover}

Proteasomal degradation of a substrate (i.e. GR $\alpha$ ) requires rounds of ubiquitination, mediated by various enzymes of the UPS (Fig. 3) to form a poly-ubiquitin chain, which the proteasome recognizes, resulting in degradation. There are number of UPS enzymes and additional co-regulators $(153,154,155,156,157,158,159)$, which interact with the GR $\alpha$ protein (Fig. 3), in a GC-dependent or independent manner, as regulators of the GR $\alpha$ pool and function. The co-regulator/GR $\alpha$ interactions, which mediate reductions in the $\mathrm{GR} \alpha$ pool via the ubiquitindependent proteasomal degradation pathway $(104,105)$ have implications in GC sensitivity and is the primary focus of this section.
The binding of two enzymes associated with the UPS, namely the inactive E2 conjugating enzyme, tumour susceptibility gene 101 (TSG101) (160) or the E3 ligase, carboxy-terminus of heat shock protein 70-interacting protein (CHIP) (161), to the GR $\alpha$ protein does not require prior ligand binding (Table 4). Moreover, whilst binding of CHIP to GR $\alpha$ is unaffected by GC treatment (139), the formation of the TSG101/GR $\alpha$ complex only occurs in the absence of ligand binding (162). Specifically, TSG101, which like the unliganded GR $\alpha$ is located in the cytoplasm, binds to the N-terminal region of the hypophosphorylated unliganded receptor and prevents protein turnover of the unliganded GR $\alpha$ by acting as a dominant negative regulator of ubiquitination due to its catalytically inactive characteristic $(162,163)$. Knockdown experiments in which TSG101 was targeted demonstrated a decrease in the stability of the hypo-phosphorylated form of $\mathrm{GR} \alpha$, thus suggesting a role for TSG101 in protecting the unliganded GR $\alpha$ from receptor turnover (162). A mutant $\mathrm{GR} \alpha$ receptor (S203A/S211A), incapable of undergoing even basal phosphorylation showed enhanced interaction with TSG101 (162), indicating that the association of GR $\alpha$ with TSG101 is dependent on the GR $\alpha$ phosphorylation status. Unlike TSG101, CHIP interactions with GR $\alpha$ seems to be phosphorylation and ligand independent, however, it appears to be a major regulator of unliganded receptor turnover (164) and its presence in the cell is vital for basal GR $\alpha$ protein turnover (139). Overexpression of CHIP in HT22 cells, where steady-state receptor levels were unaffected by prolonged hormone treatment, is able to restore GC-mediated GR $\alpha$ protein turnover, confirming a role for this E3 ligase in reducing the GR $\alpha$ pool (139).

Binding of F-box/WD repeat-containing protein 7 (FBXW7 $\alpha)$, an E3 ligase, to its substrate, requires substrate phosphorylation at a CDC4 phosphodegron

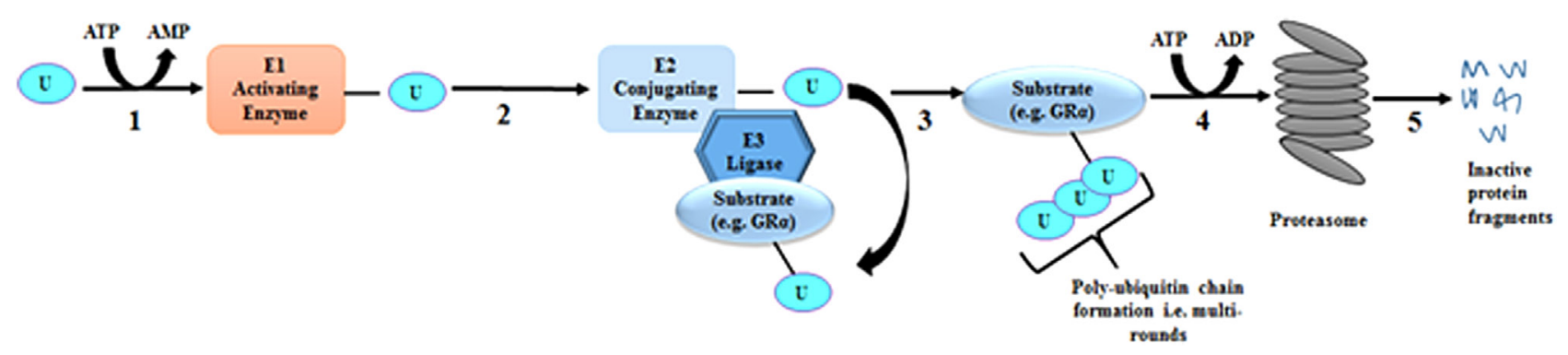

Figure 3

The ubiquitination of a substrate requires multiple rounds of a multi-step enzymatic process before being targeted to the proteasome. 1 . Ubiquitin (U) is activated by an activating enzyme (E1) in an energy (ATP)-dependent manner. 2. The activated $U$ molecule is then transferred to E2, a conjugating enzyme. 3. E3 binds the substrate and the E2 and the transfer of the activated U molecule from E2 to the substrate occurs. 4. This is repeated, until a poly-ubiquitinated chain is formed and the ubiquitinated substrate is then actively (i.e. ATP-dependent) delivered to the proteasome. 5. The catalytically active proteasome recognizes and degrades the substrate to produce inactive protein fragments.

https://ec.bioscientifica.com

https://doi.org/10.1530/EC-18-0421 (c) 2018 The authors Published by Bioscientifica Ltd

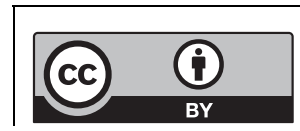

This work is licensed under a Creative Commons Attribution 4.0 International License. 
Table 4 Enzymes of the UPS that mediate GR $\alpha$ protein turnover.

\begin{tabular}{|c|c|c|c|c|c|c|c|}
\hline \multirow{3}{*}{ Enzyme } & \multirow{3}{*}{$\begin{array}{l}\text { Type of UPS } \\
\text { enzyme }\end{array}$} & \multicolumn{4}{|c|}{ Interactions with GR $\alpha$ depend on } & \multirow{3}{*}{$\begin{array}{l}\text { Role in GR } \alpha \\
\text { turnover }\end{array}$} & \multirow{3}{*}{ References } \\
\hline & & \multirow{2}{*}{\multicolumn{2}{|c|}{$\begin{array}{c}\text { Ligand-binding status } \\
\text { Unliganded }\end{array}$}} & \multicolumn{2}{|c|}{ Phosphorylation status } & & \\
\hline & & & & Нypo & Hyper & & \\
\hline TSG101 & $\begin{array}{l}\text { inactive E2 } \\
\text { conjugating } \\
\text { enzyme }\end{array}$ & Yes & No & Yes & No & $\begin{array}{l}\text { Protects } \\
\text { unliganded } \\
\text { GR } \alpha \text { from } \\
\text { turnover }\end{array}$ & (162) \\
\hline Ubch7 & $\begin{array}{l}\text { E2 conjugating } \\
\text { enzyme }\end{array}$ & No & Yes & No & Yes & $\begin{array}{l}\text { GC-mediated } \\
\text { turnover }\end{array}$ & (169) \\
\hline CHIP & E3 ligase & Yes & Yes & Yes & Yes & $\begin{array}{l}\text { GC-mediated } \\
\text { and basal } \\
\text { turnover }\end{array}$ & (139) \\
\hline $\mathrm{FBXW7} \alpha$ & E3 ligase & No & Yes & No & Yes; at S404 & $\begin{array}{l}\text { GC-mediated } \\
\text { turnover }\end{array}$ & $(136,167)$ \\
\hline $\mathrm{Mdm} 2 / \mathrm{Hdm} 2$ & E3 ligase & $\begin{array}{l}\text { Yes, but } \\
\text { requires p53 }\end{array}$ & $\begin{array}{l}\text { Yes, but } \\
\text { requires p53 }\end{array}$ & Yes & Yes & $\begin{array}{l}\text { GC-mediated } \\
\text { turnover }\end{array}$ & $(140,144,155)$ \\
\hline
\end{tabular}

motif (165) to mediate phosphorylation-dependent ubiquitination and subsequent proteasomal degradation (166). Specifically, FBXW7 $\alpha$ binding to GR $\alpha$ is primarily dependent on GSK3 $\beta$-mediated phosphorylation at S404 (136), which then targets it for proteasomal degradation (167). Malyukova et al. (167) demonstrated that a GR $\alpha$ phosphorylation mutant (S404A) was incapable of GC-mediated ubiquitination, which partially restricted its degradation via the proteasome. In addition, inactivation of FBXW7 $\alpha$, via mutations, restricted GR $\alpha$ protein turnover (167). From this evidence, it is clear that FBXW7 $\alpha$ activity and expression has implications for GC sensitivity by regulating GC-mediated reductions in the GR $\alpha$ pool.

Ubiquitin-conjugating enzyme (UbcH7), an E2-conjugating enzyme, is a known co-regulator of steroid hormone receptors (168), including the GR $\alpha$. It has been shown to modulate the function and level of the GR $\alpha$ pool, by targeting the receptor for degradation in response to GCs (169). Immunofluorescence studies have elucidated that UbcH7 is predominantly co-localized with GC-bound GR $\alpha$ in the cell's nucleus, however, cytoplasmic UbcH7 was also observed (169). Overexpression of a dominant negative form of UbcH7 preserved the GR $\alpha$ pool through increasing the stability of the receptor and restricting GC-mediated GR $\alpha$ turnover, thus confirming $\mathrm{UbcH7}$ as a key regulator of the GR $\alpha$ pool and supporting a role for UbcH7 in mediating GC sensitivity (169).

Lastly, another UPS enzyme involved in the regulation of the GR $\alpha$ pool is the E3 ligase, murine double minute 2 (i.e. Mdm2 (144) or Hdm2, the human homologue (170)). Unlike the other enzymes, Mdm2 relies on the presence of p53 to form a trimeric complex with GR $\alpha$ to mediate receptor proteasomal turnover, both in the presence and absence of GCs (155). Dex treatment of human umbilical endothelial cells enhanced GC-mediated ubiquitination of GR $\alpha$ in the presence of all three proteins (i.e. GR $\alpha$, p53 and Hdm2) (140). Furthermore, disruption of the interaction of p53 with Hdm2 prevented Dex-induced ubiquitination of GR $\alpha$ (140). Interestingly, both the presence of Mdm2 and p53 where required for oestrogenmediated GR $\alpha$ protein turnover, via the proteasomal degradation pathway (144).

\section{Strategies to restore the GR $\alpha$ pool for improved GC sensitivity}

It is clear that reductions in the GR $\alpha$ pool, whether disease-associated (Table 1), treatment-associated (Table 2), or both, contribute to the development of acquired GC resistance. With the increasing incidence of severe stress, psychological and pathological conditions, in combination with the looming threat of acquired GC resistance, a dire need exists for the development of novel GC therapeutics to combat chronic inflammation, without eliciting GC resistance.

\section{Current strategies}

In recent years, as discussed, a number of molecular mechanisms involved in GR $\alpha$ turnover have been uncovered and these have been explored and in some cases utilized in a clinical setting $(40,99,102,145)$.

For example, proteasome inhibitors, such as MG132 (104, 105), used in tissue culture cells, and bortezomib (BZ), used clinically (145) may prevent GC-induced GR $\alpha$ downregulation. Moreover, the repurposing of BZ, a Food and Drug Administration (FDA)-approved therapeutic (146), has been shown to restore GC sensitivity by preventing receptor turnover $(99,145)$. Specifically, in https://ec.bioscientifica.com https://doi.org/10.1530/EC-18-0421 (c) 2018 The authors Published by Bioscientifica Ltd

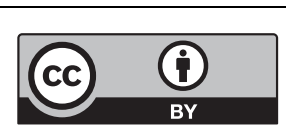

This work is licensed under a Creative Commons Attribution 4.0 International License. 
a model of hypoxic blood-brain barrier damage, $\mathrm{O}_{2} /$ glucose deprivation led to an approximate $80 \%$ reduction in the GR $\alpha$ protein pool, with BZ treatment restoring the receptor pool to $90 \%$ (in the absence of Dex) or 50\% (in the presence of Dex) (99). Importantly, this restoration in the GR $\alpha$ pool was associated with increased GC sensitivity (99). Additionally, Lesovaya et al. (145) demonstrated the ability of $\mathrm{BZ}$ to increase the anticancer activities of GCs, by maintaining the GR $\alpha$ pool through proteasomal inhibition. Although proteasomal inhibition (99, 104, $105,145)$ seems promising for restoring GC sensitivity, chronic inhibition of such a vital system for finely tuning the levels of numerous proteins (171) could be risky.

Other compounds, such as Yokukansan (YKS) (a Japanese herbal medicine for the treatment of psychiatric and psychological symptoms $(172,173))$ and Ginsenoside Rh1 (102) (a major active compound in Ginseng (174)) have also been shown to exert a protective effect against GC-mediated GR $\alpha$ turnover. Specifically, YKS counteracted by approximately $20 \%$ a stress-induced reduction in the GR $\alpha$ protein pool in mice (40) through a molecular mechanism that reduced (by almost 50\%) the expression of miR-124, which targets GR $\alpha$ mRNA. Combinatorial treatment of Ginsenoside Rh1, with Dex, restricted reductions in the $\mathrm{GR} \alpha$ pool, thus potentiating Dex's anti-inflammatory potential, specifically in prolonged treatments (102). Whilst the ability of Ginsenoside Rh1 was found to require mRNA transcription and new protein synthesis (102), suggesting its ability to transcriptionally and post-transcriptionally regulate the GR $\alpha$ pool, the exact mechanism, remains to be elucidated.

\section{Future strategies}

To date, current strategies to restore GR $\alpha$ levels for improved GC sensitivity have been based on combinatorial treatments and have not focussed on GR $\alpha$ ligands biased towards preventing a decrease in the receptor pool. Biased ligands, defined by Luttrell et al. (175) as 'novel pharmacologic entities that possess the unique ability to qualitatively change receptor signalling', may display an increased efficacy and/or a defined functional selectivity $(14,134)$, which could be harnessed to improve the therapeutic index of GCs. Additionally, Luttrell et al. (175) makes a strong case that the biological responses that arise from the interaction of a ligand with its cognate receptor are all encoded at that single point of contact with a distinct conformational change in the receptor being the initial consequence of ligand binding. Thus, conformationally biased ligands drive the conformational equilibrium towards a particular state, resulting in differential biological responses downstream.

Recently, De Bosscher et al. $(176,177)$ developed the SEMOGRAM-SEDIGRAM strategy, which is essentially based on conformationally biased ligands that induce either monomers (SEMOGRAMs) or dimers (SEDIGRAMs) of the GR for use as selective therapeutics in chronic or acute inflammation, respectively. Whilst De Bosscher et al. $(176,177)$ address selectively modulating the dimerization state of GR $\alpha$ in terms of the anti-inflammatory effects of GC signalling vs their adverse side effects, the ligand-selective effects of GR $\alpha$ conformation on receptor turnover, with implications in acquired GC resistance, are not addressed. We now suggest that co-opting the SEMOGRAM-SEDIGRAM strategy for acquired GC resistance could be fruitful and propose the idea of a 'continuum of resistance' (Fig. 4), where encouraging GR $\alpha$ dimerization though the use of SEDIGRAMs, may not only have negative implications in terms of the generation of adverse side effects $(178,179)$, but may also drive reductions in the GR $\alpha$ pool, which encourages a decrease in GC sensitivity. In contrast, the use of SEMOGRAMs, which abrogate GR dimerization, may result in reduced side effects and prevent acquired resistance while maintaining an adequate antiinflammatory potential, a therapeutic regimen more suited to chronic use.

In support of this, a wealth of pharmacological evidence supports the biased ligand behaviour of the SEMOGRAM, Compound A (CpdA) (180). The biased ligand behaviour of CpdA arises from its ability to abrogate GR $\alpha$ dimerization (181, 182), which favours transrepression of pro-inflammatory genes, which contributes to its potent immunosuppressive effects, over transactivation, generally associated with negative side effects and has proved effective in combatting inflammation in a number of in vivo models $(116,176$, $183,184,185,186,187)$ without resulting in adverse side effects $(116,184,186,188,189)$. Furthermore, CpdA does not result in ligand-induced GR $\alpha$ turnover (106, $116,135)$, an ability that may be related to its ability to abrogate GR dimerization, and as such may be considered a biased ligand able to prevent acquired resistance. In fact, recent work from our own laboratory demonstrates that dimerization impairment, either through the use of CpdA or the dimerization deficient GR mutant (GRdim), restricts $G R \alpha$ turnover via the proteasome through a molecular mechanism involving a substantial reduction in hyper-phosphorylation at Ser404 and the interaction of GR with the E3 ligase, FBXW7 $\alpha$ (190).

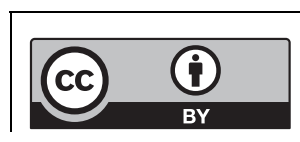

This work is licensed under a Creative Commons Attribution 4.0 International License. 


\section{'Continuum of GC resistance'}

GC sensitive

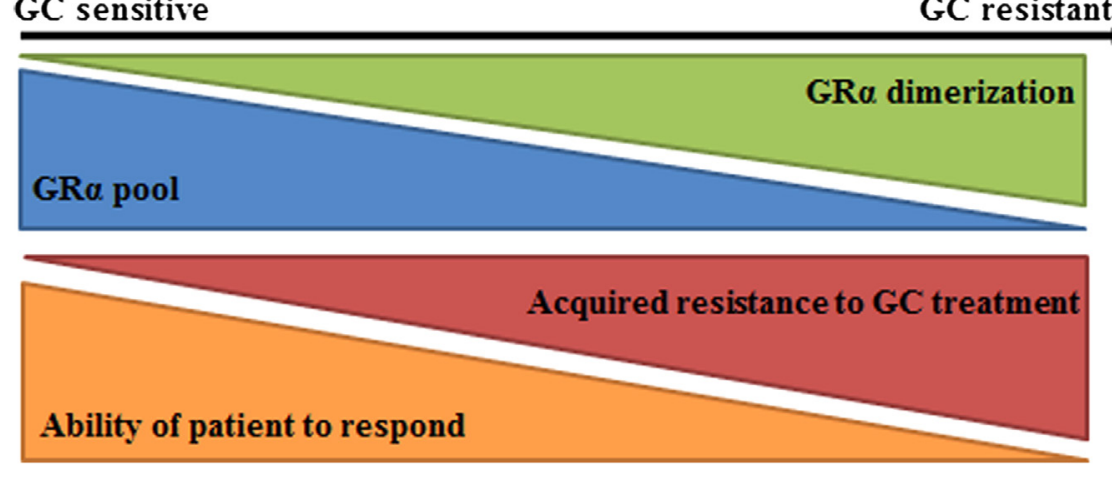

\section{Figure 4}

A 'continuum of GC resistance'. As GR $\alpha$ dimerization increases, so increased ligandinduced receptor turnover of the GR $\alpha$ pool, both at the mRNA and protein level, occurs. These significant reductions in receptor turnover, in many cases, drive the development of an acquired resistance to treatment and so the ability of a patient to respond to treatment diminishes.
Throughout this review reductions in the GR $\alpha$ pool mediated by classical GCs, such as Dex, of anywhere between 10 and $90 \%$ have been detailed, which promote GC resistance (Tables 1 and 2). Importantly, these GCs are known to induce GR $\alpha$ dimerization of the GR $\alpha$ (181, 182, 191), prior to eliciting a biological response and subsequently driving receptor turnover, and may thus be termed dimerization promoting GCs or SEDIGRAMs. On the other hand, CpdA, which displays dimerization abrogating potential and is thus a SEMOGRAM, does not induce GR $\alpha$ turnover $(106,116,135,190)$ while maintaining its immunosuppressive capabilities even during prolonged treatment regimens $(106,116)$. We believe, this begs the question of whether the dimerization state of the GR $\alpha$ is likely to influence development of an acquired resistance to treatment, in prolonged GC regimens.

Caution should, however, be exercised in overenthusiastically embracing GR ligands conformationally biased towards loss of dimerization for prevention of acquired GC resistance as our understanding of the implications of GR dimerization in GC signalling is currently limited. Accordingly, a more prudent approach may be the development of biased ligands positioned along the continuum of GC resistance (Fig. 4) rather than at the extremes of the monomer/dimer dichotomy. Nonetheless, in addition to the current strategy of combinatorial use of compounds $(99,102,145)$ that may restrict receptor turnover, we believe that disrupting dimerization through biased ligands, in a tissue-specific manner, may be a fruitful future strategy for developing tailored treatments to counteract the development of acquired GC resistance in a number of disease states. Moreover, an in-depth characterization of the dimerization capabilities (192) of GR $\alpha$ mutants (51), associated with generalized GC resistance, may provide more insight into generalized GC resistance and assist in the treatment of these rare, pathological conditions.

\section{Conclusions}

To conclude, acquired GC resistance, due to reductions in the GR $\alpha$ pool, is an ever-increasing therapeutic challenge for patients requiring chronic treatment and occurs ubiquitously throughout a number of psychological and pathological conditions. In recent years, a number of the molecular mechanisms which underpin these GC-mediated reductions in the GR $\alpha$ pool have been elucidated, with attempts to counteract GC-mediated receptor turnover being made through combinatorial treatment of GCs with other compounds, which disrupt transcriptional, post-transcriptional and post-translational $\mathrm{GR} \alpha$ regulation. Whilst in some cases, these strategies have proved fruitful, they are not without limitations. Thus, we believe the strategy of using conformationally biased ligands, specifically the SEMOGRAM-SEDIGRAM strategy, which underscores the importance of GR $\alpha$ conformation, with particular reference to the receptor's dimerization state, requires investigation and offers a novel perspective from which to approach the rational design of drugs that limit GC resistance.

\section{Declaration of interest}

The authors declare that there is no conflict of interest that could be perceived as prejudicing the impartiality of this review.

\section{Funding}

This work was supported by the National Research Foundation, South Africa (grant CPRR14072479679 to A L and PhD bursary to L W). Any opinion, findings and conclusions or recommendations expressed in this material are those of the author(s) and therefore the NRF do not accept any liability in regard thereto.

\section{Author contribution statement}

A L, N J D V and L W participated in drafting the manuscript, revising its intellectual content and approved the final version of the submitted manuscript.

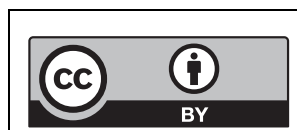

This work is licensed under a Creative Commons Attribution 4.0 International License. 


\section{References}

1 Nicolaides NC, Lamprokostopoulou A, Sertedaki A \& Charmandari E. Recent advances in the molecular mechanisms causing primary generalized glucocorticoid resistance. Hormones 201615 23-34. (https://doi.org/10.1007/BF03401400)

2 Strahler J, Skoluda N, Rohleder N \& Nater UM. Dysregulated stress signal sensitivity and inflammatory disinhibition as a pathophysiological mechanism of stress-related chronic fatigue. Neuroscience and Biobehavioral Reviews 201668 298-318. (https://doi. org/10.1016/j.neubiorev.2016.05.008)

3 Dumbell R, Matveeva O \& Oster H. Circadian clocks, stress, and immunity. Frontiers in Endocrinology 20167 1-8.

4 Cain DW \& Cidlowski JA. Specificity and sensitivity of glucocorticoid signaling in health and disease. Best Practice and Research. Clinical Endocrinology and Metabolism 201529 545-556.

5 Dendoncker K \& Libert C. Cytokine \& growth factor reviews glucocorticoid resistance as a major drive in sepsis pathology. Cytokine and Growth Factor Reviews 201735 85-96. (https://doi. org/10.1016/j.cytogfr.2017.04.002)

6 Howell BR \& Sanchez MM. Understanding behavioral effects of early life stress using the reactive scope and allostatic load models. Development and Psychopathology 201123 1001-1016. (https://doi. org/10.1017/S0954579411000460)

7 Oakley RH \& Cidlowski JA. The biology of the glucocorticoid receptor: New signaling mechanisms in health and disease. Journal of Allergy and Clinical Immunology 2013132 1033-1044. (https://doi. org/10.1016/j.jaci.2013.09.007)

8 Overman RA, Yeh JY \& Deal CL. Prevalence of oral glucocorticoid usage in the United States: a general population perspective. Arthritis Care and Research 201365 294-298. (https://doi.org/10.1002/ acr.21796)

9 Quax RA, Manenschijn L, Koper JW, Hazes JM, Lamberts SWJ, van Rossum EFC \& Feelders R. Glucocorticoid sensitivity in health and disease. Nature Reviews. Endocrinology 20139 670-686. (https://doi. org/10.1038/nrendo.2013.183)

10 Barnes PJ \& Adcock IM. Review glucocorticoid resistance in inflammatory diseases. Lancet 2009373 1905-1917. (https://doi. org/10.1016/S0140-6736(09)60326-3)

11 Haarman EG, Kaspers GJL \& Veerman AJP. Glucocorticoid resistance in childhood leukaemia: mechanisms and modulation. British Journal of Haematology 2003120 919-929. (https://doi.org/10.1046/j.13652141.2003.04189.x)

12 Williams EL, Stimpson ML, Collins PL, Enki DG, Sinha A, Lee RW \& Dhanda AD. Development and validation of a novel bioassay to determine glucocorticoid sensitivity. Biomarker Research 2016426. (https://doi.org/10.1186/s40364-016-0079-y)

13 Weikum ER, Knuesel MT, Ortlund EA \& Yamamoto KR. Glucocorticoid receptor control of transcription: precision and plasticity via allostery. Nature Reviews Molecular Cell Biology 201718 159-174. (https://doi.org/10.1038/nrm.2016.152)

14 Desmet SJ \& De Bosscher K. Glucocorticoid receptors : finding the middle ground. Journal of Clinical Investigation 2017127 1136-1145. (https://doi.org/10.1172/JCI88886)

15 Vandevyver S, Dejager L \& Libert C. Comprehensive overview of the structure and regulation of the glucocorticoid receptor. Endocrine Reviews 201435 671-693. (https://doi.org/10.1210/er.2014-1010)

16 Schaaf MJ. \& Cidlowski JA. Molecular mechanisms of glucocorticoid action and resistance. Journal of Steroid Biochemistry and Molecular Biology 200283 37-48. (https://doi.org/10.1016/S09600760(02)00263-7)

17 Cornejo S, Tantisira K, Raby BA, Weiss ST \& Kaplan F. Nuclear bioavailability of the glucocorticoid receptor in a pediatric asthma cohort with variable corticosteroid responsiveness. Pediatric Research 201578 505-512. (https://doi.org/10.1038/pr.2015.148)
18 Merkulov VM, Merkulova TI \& Bondar NP. Mechanisms of brain glucocorticoid resistance in stress-induced psychopathologies. Biochemistry 201782 351-365.

19 Beck IM, De Bosscher K \& Haegeman G. Glucocorticoid receptor mutants: man-made tools for functional research. Trends in Endocrinology and Metabolism 201122 295-310. (https://doi. org/10.1016/j.tem.2011.03.009)

20 Kushwah R, Cao H, Hu J \& Alerts E. Characterization of pulmonary $\mathrm{T}$ cell response to helper-dependent adenoviral vectors following intranasal delivery. Journal of Immunology 2008180 4098-4108. (https://doi.org/10.4049/jimmunol.180.6.4098)

21 Cardinal J, Pretorius CJ \& Ungerer JPJ. Biological and diurnal variation in glucocorticoid sensitivity detected with a sensitive in vitro dexamethasone suppression of cytokine production assay. Journal of Clinical Endocrinology and Metabolism 201095 3657-3663. (https://doi.org/10.1210/jc.2009-2720)

22 Wang H, Gou X, Jiang T \& Ouyang J. The effects of microRNAs on glucocorticoid responsiveness. Journal of Cancer Research and Clinical Oncology 2017143 1005-1011. (https://doi.org/10.1007/s00432-0172388-4)

23 Andreae J, Tripmacher R, Weltrich R, Rohde W, Keitzer R, Wahn U, Paul K \& Buttgereit F. Effect of glucocorticoid therapy on glucocorticoid receptors in children with autoimmune diseases. Pediatric Research 200149 130-135. (https://doi. org/10.1203/00006450-200101000-00025)

24 Labonte B, Yerko V, Gross J, Mechawar N, Meaney MJ, Szyf M \& Turecki G. Differential glucocorticoid receptor exon 1(B), 1(C), and $1(\mathrm{H})$ expression and methylation in suicide completers with a history of childhood abuse. Biological Psychiatry 201272 41-48. (https://doi. org/10.1016/j.biopsych.2012.01.034)

25 McGowan PO, Sasaki A, D’Alessio AC, Dymov S, Labonte B, Szyf M, Turecki G \& Meaney MJ. Epigenetic regulation of the glucocorticoid receptor in human brain associates with childhood abuse. Nature Neuroscience 200912 342-348. (https://doi. org/10.1038/nn.2270)

26 Perroud N, Rutembesa E, Paoloni-Giacobino A, Mutabaruka J, Mutesa L, Stenz L, Malafosse A \& Karege F. The Tutsi genocide and transgenerational transmission of maternal stress: epigenetics and biology of the HPA axis. World Journal of Biological Psychiatry 201415 334-345. (https://doi.org/10.3109/15622975.2013.866693)

27 Bingham BC, Sheela Rani CS, Frazer A, Strong R \& Morilak DA. Exogenous prenatal corticosterone exposure mimics the effects of prenatal stress on adult brain stress response systems and fear extinction behavior. Psychoneuroendocrinology 201338 2746-2757. (https://doi.org/10.1016/j.psyneuen.2013.07.003)

28 Navailles S, Zimnisky R \& Schmauss C. Expression of glucocorticoid receptor and early growth response gene 1 during postnatal development of two inbred strains of mice exposed to early life stress. Developmental Neuroscience 201032 139-148. (https://doi. org/10.1159/000293989)

29 Park SW, Lee JG, Mi K, Ngoc N, Chan H, Hye YC, Hein LT, Jeong A, Kim G \& Young HK. Epigenetic modification of glucocorticoid receptor promoter I 7 in maternally separated and restraint-stressed rats. Neuroscience Letters $201765038-44$. (https://doi.org/10.1016/j. neulet.2017.04.024)

30 Zhu Y, Wang Y, Yao R, Hao T, Cao J, Huang H, Wang L \& Wu Y. Enhanced neuroinflammation mediated by DNA methylation of the glucocorticoid receptor triggers cognitive dysfunction after sevoflurane anesthesia in adult rats subjected to maternal separation during the neonatal period. Journal of Neuroinflammation 2017146. (https://doi.org/10.1186/s12974-016-0782-5)

31 Arnett MG, Pan MS, Doak W, Cyr PEP, Muglia LM \& Muglia LJ. The role of glucocorticoid receptor-dependent activity in the amygdala central nucleus and reversibility of early-life stress programmed behavior. Translational Psychiatry 20155 e542. (https://doi. org/10.1038/tp.2015.35)

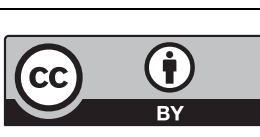

This work is licensed under a Creative Commons Attribution 4.0 International License. 
32 Niknazar S, Nahavandi A, Peyvandi AA, Peyvandi H, Roozbahany NA \& Abbaszadeh HA. Hippocampal NR3C1 DNA methylation can mediate part of preconception paternal stress effects in rat offspring. Behavioural Brain Research 2017324 71-76. (https://doi. org/10.1016/j.bbr.2017.02.014)

33 Mueller BR \& Bale TL. Sex-specific programming of offspring emotionality following stress early in pregnancy. Journal of Neuroscience 200928 9055-9065. (https://doi.org/10.1523/ JNEUROSCI.1424-08.2008)

34 Lan N, Chiu MPY, Ellis L \& Weinberg J. Prenatal alcohol exposure and prenatal stress differentially alter glucocorticoid signaling in the placenta and fetal brain. Neuroscience 2017342 167-179. (https://doi. org/10.1016/j.neuroscience.2015.08.058)

35 Smart C, Strathdee G, Watson S, Murgatroyd C \& McAllisterWilliams RH. Early life trauma, depression and the glucocorticoid receptor gene - an epigenetic perspective. Psychological Medicine 2015 44 1-18.

36 Zannas AS \& Chrousos GP. Epigenetic programming by stress and glucocorticoids along the human lifespan. Molecular Psychiatry 2017 22 640-646. (https://doi.org/10.1038/mp.2017.35)

37 Witzmann SR, Turner JD, Meriaux SB, Meijer OC \& Muller CP. Epigenetic regulation of the glucocorticoid receptor promoter $17 \mathrm{in}$ adult rats. Epigenetics 20127 1290-1301. (https://doi.org/10.4161/ epi.22363)

38 Jung SH, Wang Y, Kim T, Tarr A, Reader B, Powell N \& Sheridan JF. Molecular mechanisms of repeated social defeat-induced glucocorticoid resistance: role of microRNA. Brain, Behavior, and Immunity 201544 195-206. (https://doi.org/10.1016/j. bbi.2014.09.015)

39 Makhathini KB, Abboussi O, Stein DJ, Mabandla MV \& Daniels WMU. Repetitive stress leads to impaired cognitive function that is associated with DNA hypomethylation, reduced BDNF and a dysregulated HPA axis. International Journal of Developmental Neuroscience 201760 63-69. (https://doi.org/10.1016/j. ijdevneu.2017.04.004)

40 Shimizu S, Tanaka T, Tohyama M \& Miyata S. Yokukansan normalizes glucocorticoid receptor protein expression in oligodendrocytes of the corpus callosum by regulating microRNA-124a expression after stress exposure. Brain Research Bulletin 2015114 49-55. (https://doi. org/10.1016/j.brainresbull.2015.03.007)

41 Chiba S, Numakawa T, Ninomiya M, Richards MC, Wakabayashi C \& Kunugi H. Chronic restraint stress causes anxiety- and depression-like behaviors, downregulates glucocorticoid receptor expression, and attenuates glutamate release induced by brain-derived neurotrophic factor in the prefrontal cortex. Progress in Neuro-Psychopharmacology and Biological Psychiatry 201239 112-119. (https://doi.org/10.1016/j. pnpbp.2012.05.018)

42 Mifsud KR, Saunderson EA, Spiers H, Carter SD, Trollope AF, Mill J \& Reul JMHM. Rapid down-regulation of glucocorticoid receptor gene expression in the dentate gyrus after acute stress in vivo: role of DNA methylation and microRNA activity. Neuroendocrinology $2016 \mathbf{1 0 4}$ 157-169. (https://doi.org/10.1159/000445875)

43 Quan N, Avitsur R, Stark JL, He L, Lai W, Dhabhar F \& Sheridan JF Molecular mechanisms of glucocorticoid resistance in splenocytes of socially stressed male mice. Journal of Neuroimmunology 2003137 51-58. (https://doi.org/10.1016/S0165-5728(03)00042-0)

44 Han Q, Yang L, Huang H, Wang Y, Yu R \& Wang J. Differential GR expression and translocation in the hippocampus mediates susceptibility vs . resilience to chronic social defeat stress. Frontiers in Neuroscience 201711 1-10.

45 Li B, Duan XH, Wu JF, Liu BJ, Luo QL, Jin HL, Du YJ, Zhang HY, Cao YX \& Dong JC. Impact of psychosocial stress on airway inflammation and its mechanism in a murine model of allergic asthma. Chinese Medical Journal 2013126 325-334.

46 Tyrka AR, Price LH, Marsit C, Walters OC \& Carpenter LL. Childhood adversity and epigenetic modulation of the leukocyte glucocorticoid receptor: Preliminary findings in healthy adults. PLOS ONE 20127 e30148. (https://doi.org/10.1371/journal.pone.0030148)

47 Tyrka AR, Parade SH, Welch ES, Ridout KK, Price LH, Marsit C, Philip NS \& Carpenter LL. Methylation of the leukocyte glucocorticoid receptor gene promoter in adults : associations with early adversity and depressive, anxiety and substance-use disorders. $20166 \mathrm{e} 848$.

48 Owens MJ \& Nemeroff CB. The role of corticotropin-releasing factor in the pathophysiology of affective and anxiety disorders: laboratory and clinical studies. Ciba Foundation Symposium 2007172 296-316.

49 Lopez JF, Chalmers DT, Little KY \& Watson SJ. Regulation of serotonin (1A), glucocorticoid, and mineralocorticoid receptor in rat and human hippocampus: Implications for the neurobiology of depression. Biological Psychiatry 199843 547-573. (https://doi. org/10.1016/S0006-3223(97)00484-8)

50 Pariante CM. Why are depressed patients inflamed? A reflection on 20 years of research on depression, glucocorticoid resistance and inflammation. European Neuropsychopharmacology 201727 554-559. (https://doi.org/10.1016/j.euroneuro.2017.04.001)

51 Spencer R, Williams EL, Stimpson ML, Collins PL, Enki DG, Sinha A, Lee RW, Dhanda AD, Spijker AT, Cardinal J, et al. Synthesis of novel steroidal agonists, partial agonists, and antagonists for the glucocorticoid receptor. Bioorganic and Medicinal Chemistry Letters 201727 347-353. (https://doi. org/10.1016/j.bmcl.2016.11.007)

52 Cattaneo A, Gennarelli M, Uher R, Breen G, Farmer A, Aitchison KJ, Craig IW, Anacker C, Zunsztain PA, McGuffin P, et al. Candidate genes expression profile associated with antidepressants response in the GENDEP study: differentiating between baseline 'predictors' and longitudinal 'targets'. Neuropsychopharmacology 201338 377-385. (https://doi.org/10.1038/npp.2012.191)

53 Nikkheslat N, Zunszain PA, Horowitz MA, Barbosa IG, Parker JA, Myint A, Schwarz MJ, Tylee AT, Carvalho LA \& Pariante CM. Insufficient glucocorticoid signaling and elevated inflammation in coronary heart disease patients with comorbid depression. Brain Behavior and Immunity 201548 8-18. (https://doi.org/10.1016/j. bbi.2015.02.002)

54 Matsubara T, Funato H, Kobayashi A, Nobumoto M \& Watanabe Y. Reduced glucocorticoid receptor alpha expression in mood disorder patients and first-degree relatives. Biological Psychiatry 200659 689-695. (https://doi.org/10.1016/j.biopsych.2005.09.026)

55 Wang W, Feng J, Ji C, Mu X, Ma Q, Fan Y, Chen C, Gao C, Ma X $\&$ Zhu F. Increased methylation of glucocorticoid receptor gene promoter $1 \mathrm{~F}$ in peripheral blood of patients with generalized anxiety disorder. Journal of Psychiatric Research 201791 18-25. (https://doi. org/10.1016/j.jpsychires.2017.01.019)

56 Matić G, Milutinović DV, Nestorov J, Elaković I, Jovanović SM, Perišić T, Dunderski J, Damjanović S, Knežević G, Špirić Ž, et al. Lymphocyte glucocorticoid receptor expression level and hormonebinding properties differ between war trauma-exposed men with and without PTSD. Progress in Neuro-Psychopharmacology and Biological Psychiatry 201343 238-245.

57 Gola H, Engler A, Morath J, Adenauer H, Elbert T, Kolassa IT \& Engler $\mathrm{H}$. Reduced peripheral expression of the glucocorticoid receptor $\alpha$ isoform in individuals with posttraumatic stress disorder: a cumulative effect of trauma burden. PLoS ONE 20149 e86333. (https://doi.org/10.1371/journal.pone.0086333)

58 Webster M, Knable M, O’ Grady J, Orthmann J \& Weickert C. Regional specificity of brain glucocorticoid receptor mRNA alterations in subjects with schizophrenia and mood disorders. Molecular Psychiatry 20027 985-994. (https://doi.org/10.1038/ sj.mp.4001139)

59 Gotovac K, Sabioncello A, Rabati S, Berki T \& Dekaris D. Flow cytometric determination of glucocorticoid receptor (GCR) expression in lymphocyte subpopulations: Lower quantity of GCR in patients with post-traumatic stress disorder (PTSD). Clinical
This work is licensed under a Creative Commons Attribution 4.0 International License. 
and Experimental Immunology 2003131 335-339. (https://doi. org/10.1046/j.1365-2249.2003.02075.x)

60 Bloomfield D \& Smith A. Glucocorticoids and lymphocytes. Blood 201761 1086-1090.

61 Inui S, Sumikawa Y, Asada H \& Itami S. Glucocorticoid resistance in atopic dermatitis associated with decreased expression of glucocorticoid receptor-alpha in peripheral blood mononuclear cells. Journal of Dermatology 201037 496-499. (https://doi.org/10.1111/ j.1346-8138.2010.00866.x)

62 Chen H, Fan J, Shou Q, Zhang L, Ma H \& Fan Y. Hypermethylation of glucocorticoid receptor gene promoter results in glucocorticoid receptor gene low expression in peripheral blood mononuclear cells of patients with systemic lupus erythematosus. Rheumatology International 201535 1335-1342. (https://doi.org/10.1007/s00296-015-3266-5)

63 Wang Y, Pang C, Ma X, An Y \& Feng X. Role of glucocorticoid receptor in the pathogenesis of systemic lupus erythematosus. Journal of Peking University. Health Sciences 201244 229-232.

64 Guan Y, Zhang Y, Fang M, Guan J, Sun X \& Zhang J. The relationship between mRNA level of glucocorticoid receptor $\alpha$, heat shock protein 90, protein level of macrophage migration inhibitory factor and glucocorticoid resistance in systemic lupus erythematosus. Zhonghua nei ke za zhi 201554 922-926.

65 Ma L, Fang M, Liang Y, Xiang Y, Jia Z, Sun X, Wang Y \& Qin J. Low expression of glucocorticoid receptor alpha isoform in adult immune thrombocytopenia correlates with glucocorticoid resistance. Annals of Hematology 201392 953-960. (https://doi. org/10.1007/s00277-013-1705-5)

66 Sousa AR, Lane SJ, Cidlowski JA, Staynov DZ \& Lee TH. Glucocorticoid resistance in asthma is associated with elevated in vivo expression of the glucocorticoid receptor $\beta$-isoform. Journal of Allergy and Clinical Immunology 2000105 943-950. (https://doi. org/10.1067/mai.2000.106486)

67 Sher ER, Leung DYM, Surs W, Kam JC, Zieg G, Kamada AK \& Szefler SJ. Steroid-resistant asthma. Cellular mechanisms contributing to inadequate response to glucocorticoid therapy. Journal of Clinical Investigation 199493 33-39. (https://doi.org/10.1172/JCI116963)

68 Pujols L, Xaubet A, Ramírez J, Mullol J, Roca-Ferrer J, Torrego A, Cidlowski JA \& Picado C. Expression of glucocorticoid receptors alpha and beta in steroid sensitive and steroid insensitive interstitial lung diseases. Thorax 200459 687-693. (https://doi.org/10.1136/ thx.2003.013268)

69 Marwick JA, Caramori G, Stevenson CS, Casolari P, Jazrawi E, Barnes PJ, Ito K, Adcock IM, Kirkham PA \& Papi A. Inhibition of PI3Kס restores glucocorticoid function in smoking-induced airway inflammation in mice. American Journal of Respiratory and Critical Care Medicine 2009179 542-548. (https://doi.org/10.1164/rccm.2008101570OC)

70 Hodge G, Jersmann H, Tran HB, Holmes M, Reynolds PN \& Hodge S. Lymphocyte senescence in COPD is associated with loss of glucocorticoid receptor expression by pro-inflammatory/ cytotoxic lymphocytes. Respiratory Research 201516 2. (https://doi. org/10.1186/s12931-014-0161-7)

71 Hodge G, Roscioli E, Jersmann H, Tran HB, Holmes M, Reynolds PN $\&$ Hodge S. Steroid resistance in COPD is associated with impaired molecular chaperone Hsp90 expression by pro-inflammatory lymphocytes. Respiratory Research 201617 135. (https://doi. org/10.1186/s12931-016-0450-4)

72 Kozaci DL, Chernajovsky Y \& Chikanza IC. The differential expression of corticosteroid receptor isoforms in corticosteroidresistant and -sensitive patients with rheumatoid arthritis. Rheumatology 200746 579-585. (https://doi.org/10.1093/ rheumatology/kel276)

73 Schlaghecke R, Beuscher D, Kornely E \& Specker C. Effects of glucocorticoids in rheumatoid arthritis. Diminished glucocorticoid receptors do not result in glucocorticoid resistance. Arthritis and Rheumatism 199437 1127-1131.
74 Dibattista JA, Martel-Pelletier J, Antakly T, Tardif G, Cloutier JM \& Pelletier JP. Reduced expression of glucocorticoid receptor levels in human osteoarthritic chondrocytes. Role in the suppression of metalloprotease synthesis. Journal of Clinical Endocrinology and Metabolism 199376 1128-1134.

75 Creed TJ \& Probert CSJ. Review article: steroid resistance in inflammatory bowel disease-mechanisms and therapeutic strategies. Alimentary Pharmacology and Therapeutics 200725 111-122.

76 Raddatz D, Middel P, Bockemuhl M, Benohr P, Wissmann C, Schworer H, Ramadori G, Bockemühl M, Benöhr P \& Schwörer H. Glucocorticoid receptor expression in inflammatory bowel disease: evidence for a mucosal down-regulation in steroid-unresponsive ulcerative colitis. Alimentary Pharmacology and Therapeutics 200419 47-61. (https://doi.org/10.1046/j.1365-2036.2003.01802.x)

77 Gold SM, Sasidhar MV, Lagishetty V, Spence RD, Umeda E, Ziehn MO, Krieger T, Schulz KH, Heesen C, Hewison M, et al. Dynamic development of glucocorticoid resistance during autoimmune neuroinflammation. Journal of Clinical Endocrinology and Metabolism 201297 1402-1410. (https://doi.org/10.1210/jc.2012-1294)

78 Taylor KM, Ray DW \& Sommer P. Glucocorticoid receptors in lung cancer: new perspectives. Journal of Endocrinology 2016229 R17-R28. (https://doi.org/10.1530/JOE-15-0496)

79 Patki M, Gadgeel S, Huang Y, McFall T, Shields AF, Matherly LH, Bepler G \& Ratnam M. Glucocorticoid receptor status is a principal determinant of variability in the sensitivity of non-small-cell lung cancer cells to pemetrexed. Journal of Thoracic Oncology 20149 519-526. (https://doi.org/10.1097/JTO.0000000000000111)

80 Sommer P, Cowen RL, Berry A, Cookson A, Telfer BA, Williams KJ, Stratford IJ, Kay P, White A \& Ray DW. Glucocorticoid receptor overexpression promotes human small cell lung cancer apoptosis in vivo and thereby slows tumor growth. Endocrine-Related Cancer 201017 203-213. (https://doi.org/10.1677/ERC-09-0241)

81 Kay P, Schlossmacher G, Matthews L, Sommer P, Singh D, White A \& Ray D. Loss of glucocorticoid receptor expression by DNA methylation prevents glucocorticoid induced apoptosis in human small cell lung cancer cells. PLOS ONE 20116 e24839. (https://doi. org/10.1371/journal.pone.0024839)

82 Schlossmacher G, Platt E, Davies A, Meredith S \& White A. Glucocorticoid receptor-mediated apoptosis in small-cell lung cancer requires interaction with BCL2. Endocrine-Related Cancer 201320 785-795. (https://doi.org/10.1530/ERC-13-0402)

83 Schmidt S, Irving JE, Minto L, Matheson E, Nicholson L, Ploner A, Parson W, Kofler A, Amort M, Erdel M, et al. Glucocorticoid resistance in two key models of acute lymphoblastic leukemia occurs at the level of the glucocorticoid receptor. FASEB Journal 200620 2600-2602. (https://doi.org/10.1096/fj.06-6214fje)

84 Lv M, Zhang X, Jia H, Li D, Zhang B, Zhang H, Hong M, Jiang T, Jiang Q, Lu J, et al. An oncogenic role of miR-142-3p in human T-cell acute lymphoblastic leukemia (T-ALL) by targeting glucocorticoid receptor- $\alpha$ and cAMP/PKA pathways. Leukemia 201226 769-777. (https://doi.org/10.1038/leu.2011.273)

85 Jones CL, Gearheart CM, Fosmire S, Delgado-Martin C, Evensen NA, Bride K, Waanders AJ, Pais F, Wang J, Bhatla T, et al. MAPK signaling cascades mediate distinct glucocorticoid resistance mechanisms in pediatric leukemia. Blood 2015126 2202-2212. (https://doi. org/10.1182/blood-2015-04-639138)

86 Tissing WJE, Meijerink JPP, den Boer ML \& Pieters R. Molecular determinants of glucocorticoid sensitivity and resistance in acute lymphoblastic leukemia. Leukemia 200317 17-25. (https://doi. org/10.1038/sj.leu.2402733)

87 Greenstein S, Krett NL, Kurosawa Y, Ma C, Chauhan D, Hideshima T, Anderson KC \& Rosen ST. Characterization of the MM.1 human multiple myeloma (MM) cell lines: a model system to elucidate the characteristics, behavior, and signaling of steroid-sensitive and -resistant MM cells. Experimental Hematology 200331 271-282. (https://doi.org/10.1016/S0301-472X(03)00023-7)

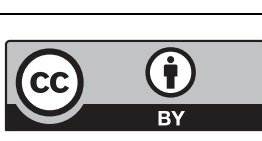

This work is licensed under a Creative Commons Attribution 4.0 International License. 
88 Chauhan D, Auclair D, Robinson EK, Hideshima T, Li G, Podar K, Gupta D, Richardson P, Schlossman RL, Krett N, et al. Identification of genes regulated by Dexamethasone in multiple myeloma cells using oligonucleotide arrays. Oncogene 20026 1346-1358. (https:// doi.org/10.1038/sj.onc.1205205)

89 Tessel MA, Benham AL, Krett NL, Rosen ST \& Gunaratne PH. Role for microRNAs in regulating glucocorticoid response and resistance in multiple myeloma. Hormonal Cancer 201318 1199-1216.

90 Sánchez-Vega B \& Gandhi V. Glucocorticoid resistance in a multiple myeloma cell line is regulated by a transcription elongation block in the glucocorticoid receptor gene (NR3C1). British Journal of Haematology 2009144 856-864.

91 Heuck CJ, Szymonifka J, Hansen E, Shaughnessy JD, Usmani SZ, Van Rhee F, Anaissie E, Nair B, Waheed S, Alsayed Y, et al. Thalidomide in total therapy 2 overcomes inferior prognosis of myeloma with low expression of the glucocorticoid receptor gene NR3C1. Clinical Cancer Research 201218 5499-5506. (https://doi.org/10.1158/1078-0432. CCR-12-0019)

92 Nesset KA, Perri AM \& Mueller CR. Frequent promoter hypermethylation and expression reduction of the glucocorticoid receptor gene in breast tumors. Epigenetics 20149 851-859. (https:// doi.org/10.4161/epi.28484)

93 Lien HC, Lu YS, Cheng AL, Chang WC, Jeng YM, Kuo YH, Huang CS, Chang KJ \& Yao YT. Differential expression of glucocorticoid receptor in human breast tissues and related neoplasms. Journal of Pathology 2006209 317-327. (https://doi.org/10.1002/path.1982)

94 Vanderbilt JN, Miesfeld R, Maler BA \& Yamamoto KR. Intracellular receptor concentration limits glucocorticoid-dependent enhancer activity. Molecular Endocrinology 19871 68-74. (https://doi. org/10.1210/mend-1-1-68)

95 Ledderose C, Möhnle P, Limbeck E, Schütz S, Weis F, Rink J, Briegel J \& Kreth S. Corticosteroid resistance in sepsis is influenced by microRNA-124--induced downregulation of glucocorticoid receptor- $\alpha$. Critical Care Medicine 201240 2745-2753. (https://doi. org/10.1097/CCM.0b013e31825b8ebc)

96 Van Den Akker ELT, Koper JW, Joosten K, De Jong FH, Hazelzet JA, Lamberts SWJ \& Hokken-Koelega ACS. Glucocorticoid receptor mRNA levels are selectively decreased in neutrophils of children with sepsis. Intensive Care Medicine 200935 1247-1254. (https://doi. org/10.1007/s00134-009-1468-6)

97 Hammad A, Yahia S, Gouida MS, Bakr A \& El-Farahaty RM. Low expression of glucocorticoid receptors in children with steroidresistant nephrotic syndrome. Pediatric Nephrology 201328 759-763. (https://doi.org/10.1007/s00467-012-2385-4)

98 Rutkowski D, Syed F, Matthews LC, Ray DW, McGrouther DA, Watson REB \& Bayat A. An abnormality in glucocorticoid receptor expression differentiates steroid responders from non-responders in keloid disease. British Journal of Dermatology 2015173 690-700. (https://doi.org/10.1111/bjd.13752)

99 Kleinschnitz C, Blecharz K, Kahles T, Schwarz T, Kraft P, Göbel K, Meuth SG, Burek M, Thum T, Stoll G, et al. Glucocorticoid insensitivity at the hypoxic blood-brain barrier can be reversed by inhibition of the proteasome. Stroke 201142 1081-1089. (https://doi. org/10.1161/STROKEAHA.110.592238)

100 Griese M, Kusenbach G, Lüsebring K, Köster W, Roth B \& Reinhardt D. Glucocorticoid receptors in mononuclear blood cells and their correlation to endogenous and exogenous corticoids in healthy and asthmatic children. European Journal of Pediatrics 1988 147 490-495. (https://doi.org/10.1007/BF00441973)

101 Urzua CA, Guerrero J, Gatica H, Velasquez V \& Goecke A. Evaluation of the glucocorticoid receptor as a biomarker of treatment response in Vogt-Koyanagi-Harada disease. Investigative Opthalmology and Visual Science 201758 974. (https://doi.org/10.1167/iovs.16-20783)

102 Li J, Du J, Liu D, Cheng B, Fang F, Weng L, Wang C \& Ling C. Ginsenoside Rh1 potentiates dexamethasone's anti-inflammatory effects for chronic inflammatory disease by reversing dexamethasone-induced resistance. Arthritis Research and Therapy 201416 R106. (https://doi.org/10.1186/ar4556)

103 Silva CM, Powell-Oliver FE, Jewell CM, Sar M, Allgood VE \& Cidlowski JA. Regulation of the human glucocorticoid receptor by long-term and chronic treatment with glucocorticoid. Steroids 1994 59 436-442. (https://doi.org/10.1016/0039-128X(94)90013-2)

104 Wallace AD \& Cidlowski JA. Proteasome-mediated glucocorticoid receptor degradation restricts transcriptional signaling by glucocorticoids. Journal of Biological Chemistry 2001276 42714-42721. (https://doi.org/10.1074/jbc.M106033200)

105 Wallace AD, Cao Y, Chandramouleeswaran S \& Cidlowski JA. Lysine 419 targets human glucocorticoid receptor for proteasomal degradation. Steroids 201075 1016-1023. (https://doi.org/10.1016/j. steroids.2010.06.015)

106 Visser K, Smith C \& Louw A. Interplay of the inflammatory and stress systems in a hepatic cell line: interactions between glucocorticoid receptor agonists and interleukin-6. Endocrinology $2010 \mathbf{1 5 1}$ 5279-5293. (https://doi.org/10.1210/en.2010-0368)

107 Ramamoorthy S \& Cidlowski JA. Ligand-induced repression of the glucocorticoid receptor gene is mediated by an NCoR1 repression complex formed by long-range chromatin interactions with intragenic glucocorticoid response elements. Molecular and Cellular Biology 201333 1711-1722. (https://doi.org/10.1128/MCB.01151-12)

108 Pujols L, Mullol J, Perez M, Roca-Ferrer J, Juan M, Xaubet A, Cidlowski JA \& Picado C. Expression of the human glucocorticoid receptor alpha and beta isoforms in human respiratory epithelial cells and their regulation by dexamethasone. American Journal of Respiratory Cell and Molecular Biology 200124 49-57. (https://doi. org/10.1165/ajrcmb.24.1.4024)

109 Ling C, Li Y, Zhu X, Zhang C \& Li M. Ginsenosides may reverse the dexamethasone-induced down-regulation of glucocorticoid receptor. General and Comparative Endocrinology 2005140 203-209. (https:// doi.org/10.1016/j.ygcen.2004.11.003)

110 Dekelbab BH, Witchel SF, \& DeFranco DB. TNF-alpha and glucocorticoid receptor interaction in L6 muscle cells: a cooperative downregulation of myosin heavy chain. Steroids $2007 \mathbf{7 2} 705-712$. (https://doi.org/10.1016/j.steroids.2007.05.007)

111 Sun Y, Wan X, Ouyang J, Xie R, Wang X \& Chen P. Prenatal dexamethasone exposure increases the susceptibility to autoimmunity in offspring rats by epigenetic programing of glucocorticoid receptor. BioMed Research International 20162016 1-9.

112 Bellingham DL, Sar M \& Cidlowski JA. Ligand-dependent downregulation of stably transfected human glucocorticoid receptors is associated with the loss of functional glucocorticoid responsiveness. Molecular Endocrinology 19926 2090-2102.

113 Zhang B, Zhang Y, Xu T, Yin Y, Huang R, Wang Y, Zhang J, Huang D \& Li W. Chronic dexamethasone treatment results in hippocampal neurons injury due to activate NLRP1 inflammasome in vitro. International Immunopharmacology 201749 222-230. (https://doi. org/10.1016/j.intimp.2017.05.039)

114 Guess A, Agrawal S, Wei CC, Ransom RF, Benndorf R \& Smoyer WE. Dose- and time-dependent glucocorticoid receptor signaling in podocytes. American Journal of Physiology. Renal Physiology 2010299 F845-F853. (https://doi.org/10.1152/ajprenal.00161.2010)

115 Hu W, Zhang Y, Wu W, Yin Y, Huang D, Wang Y, Li W \& Li W. Chronic glucocorticoids exposure enhances neurodegeneration in the frontal cortex and hippocampus via NLRP-1 inflammasome activation in male mice. Brain, Behavior, and Immunity 201652 58-70. (https://doi.org/10.1016/j.bbi.2015.09.019)

116 Gossye V, Elewaut D, Van Beneden K, Dewint P, Haegeman G, \& De Bosscher K. A plant-derived glucocorticoid receptor modulator attenuates inflammation without provoking ligand-induced resistance. Annals of the Rheumatic Diseases 201069 291-296. (https://doi.org/10.1136/ard.2008.102871)

117 Barrett TJ, Vig E \& Vedeckis WV. Coordinate regulation of glucocorticoid receptor and c- jun gene expression is cell
This work is licensed under a Creative Commons Attribution 4.0 International License. 
type-specific and exhibits differential hormonal sensitivity for downand up-regulation. Biochemistry 199635 9746-9753. (https://doi. org/10.1021/bi960058j)

118 Djordjevic-Markovic R, Radic O, Jelic V, Radojcic M, RapicOtrin V, Ruzdijic S, Krstic-Demonacos M, Kanazir S \& Kanazir D. Glucocorticoid receptors in ageing rats. Experimental Gerontology 1999 34 971-982. (https://doi.org/10.1016/S0531-5565(99)00067-4)

119 Shimojo M. Differences in down-regulation of glucocorticoid receptor mRNA by cortisol, prednisolone and dexamethasone in HeLa cells. Journal of the Medical Society of Toho University 199542 331-338.

120 Peeters RP, Hagendorf A, Vanhorebeek I, Visser TJ, Klootwijk W, Mesotten D, Wouters PJ, Koper JW, De Jong FH, Feelders RA, et al. Tissue mRNA expression of the glucocorticoid receptor and its splice variants in fatal critical illness. Clinical Endocrinology $2009 \mathbf{7 1}$ 145-153. (https://doi.org/10.1111/j.1365-2265.2008.03443.x)

121 Vachier I, Roux S, Chanez P, Loubatière J, Térouanne B, Nicolas JC \& Godard P. Glucocorticoids induced down-regulation of glucocorticoid receptor mRNA expression in asthma. Clinical and Experimental Immunology 1996103 311-315. (https://doi. org/10.1046/j.1365-2249.1996.d01-628.x)

122 Berki T, Tavakoli A, Nagy KK, Nagy G \& Nemeth P. Alterations of glucocorticoid receptor expression during glucocorticoid hormone therapy in renal transplant patients. Transplant International $2002 \mathbf{1 5}$ 132-138. (https://doi.org/10.1111/j.1432-2277.2002.tb00140.x)

123 Hollenberg SM, Weinberger C, Ong ES, Cerelli G, Oro A, Lebo R, Thompson EB, Rosenfeld MG \& Evans RM. Primary structure and expression of a functional human glucocorticoid receptor cDNA. Nature 1985318 635-641. (https://doi.org/10.1038/318635a0)

124 Surjit M, Ganti KP, Mukherji A, Ye T, Hua G, Metzger D, Li M \& Chambon P. Widespread negative response elements mediate direct repression by agonist-liganded glucocorticoid receptor. Cell 2011145 224-241. (https://doi.org/10.1016/j.cell.2011.03.027)

125 Schaaf MJ \& Cidlowski JA. AUUUA motifs in the 3'UTR of human glucocorticoid receptor alpha and beta mRNA destabilize mRNA and decrease receptor protein expression. Steroids 200267 627-636. (https://doi.org/10.1016/S0039-128X(02)00015-6)

126 Lam JKW, Chow MYT, Zhang Y \& Leung SWS. siRNA versus miRNA as therapeutics for Gene Silencing. Molecular Therapy-Nucleic Acids 20154 e252.

127 Riester A, Issler O, Spyroglou A, Rodrig SH, Chen A \& Beuschlein F. ACTH-dependent regulation of microRNA as endogenous modulators of glucocorticoid receptor expression in the adrenal gland. Endocrinology 2012153 212-222. (https://doi.org/10.1210/en.20111285)

128 Uchida S, Nishida A, Hara K, Kamemoto T, Suetsugi M, Fujimoto M, Watanuki T, Wakabayashi Y, Otsuki K, McEwen BS, et al. Characterization of the vulnerability to repeated stress in Fischer 344 rats: Possible involvement of microRNA-mediated down-regulation of the glucocorticoid receptor. European Journal of Neuroscience 2008 27 2250-2261. (https://doi.org/10.1111/j.1460-9568.2008.06218.x)

129 Vreugdenhil E, Verissimo CSL, Mariman R, Kamphorst JT, Barbosa JS, Zweers T, Champagne DL, Schouten T, Meijer OC, De Kloet ER, et al. Glucocorticoid Receptor : Implications for Glucocorticoid Responsiveness in the Brain. Endocrinology $20091502220-2228$. (https://doi.org/10.1210/en.2008-1335)

130 Liang YN, Tang YL, Ke ZY, Chen YQ, Luo XQ, Zhang H \& Huang LB. MiR-124 contributes to glucocorticoid resistance in acute lymphoblastic leukemia by promoting proliferation, inhibiting apoptosis and targeting the glucocorticoid receptor. Journal of Steroid Biochemistry and Molecular Biology 2017172 62-68. (https://doi. org/10.1016/j.jsbmb.2017.05.014)

131 Anbalagan M, Huderson B, Murphy L \& Rowan BG. Posttranslational modifications of nuclear receptors and human disease. Nuclear Receptor Signaling 201210 1-13. (https://doi.org/10.1621/ nrs.10001)
132 Kadmiel M \& Cidlowski JA. Glucocorticoid receptor signaling in health and disease. Trends in Pharmacological Sciences 201334 518-530. (https://doi.org/10.1016/j.tips.2013.07.003)

133 Nicolaides NC, Galata Z, Kino T, Chrousos GP \& Charmandari E. The human glucocorticoid receptor: molecular basis of biologic function. Steroids 201075 1-12. (https://doi.org/10.1016/j. steroids.2009.09.002)

134 Ramamoorthy S \& Cidlowski JA. Corticosteroids-mechanisms of action in health and disease. Rheumatic Diseases Clinics of North America 20168 583-592. (https://doi.org/10.1016/j. rdc.2015.08.002)

135 Avenant C, Ronacher K, Stubsrud E, Louw A \& Hapgood JP. Role of ligand-dependent GR phosphorylation and half-life in determination of ligand-specific transcriptional activity. Molecular and Cellular Endocrinology 2010327 72-88. (https://doi.org/10.1016/j. mce.2010.06.007)

136 Galliher-Beckley AJ, Williams JG, Collins JB \& Cidlowski JA. Glycogen synthase kinase 3 $\beta$-mediated serine phosphorylation of the human glucocorticoid receptor redirects gene expression profiles. Molecular and Cellular Biology 200828 7309-7322. (https://doi. org/10.1128/MCB.00808-08)

137 Webster JC, Jewell CM, Bodwell JE, Munck A, Sar M \& Cidlowski JA Mouse glucocorticoid receptor phosphorylation status influences multiple functions of the receptor protein. Journal of Biological Chemistry 1997272 9287-9293. (https://doi.org/10.1074/ jbc.272.14.9287)

138 Webster JC \& Cidlowski JA. Downregulation of the glucocorticoid receptor. A mechanism for physiological adaptation to hormones. Annals of the New York Academy of Sciences 1994746 216-220. (https://doi.org/10.1111/j.1749-6632.1994.tb39238.x)

139 Wang X \& DeFranco DB. Alternative effects of the ubiquitinproteasome pathway on glucocorticoid receptor down-regulation and transactivation are mediated by CHIP, an E3 ligase. Molecular Endocrinology 200519 1474-1482. (https://doi.org/10.1210/me.20040383)

140 Sengupta S \& Wasylyk B. Ligand-dependent interaction of the glucocorticoid receptor with p53 enhances their degradation by Hdm2. Genes and Development 200115 2367-2380. (https://doi. org/10.1101/gad.202201)

141 Sultana R, Theodoraki MA \& Caplan AJ. Specificity in the actions of the UBR1 ubiquitin ligase in the degradation of nuclear receptors. FEBS Open Bio 20133 394-397. (https://doi.org/10.1016/j. fob.2013.09.003)

142 Wang X, Pongrac JL \& DeFranco DB. Glucocorticoid receptors in hippocampal neurons that do not engage proteasomes escape from hormone-dependent down-regulation but maintain transactivation activity. Molecular Endocrinology 200216 1987-1998. (https://doi. org/10.1210/me.2001-0287)

143 Deroo BJ, Rentsch C, Sampath S, Young J, DeFranco DB \& Archer TK. Proteasomal inhibition enhances glucocorticoid receptor transactivation and alters its subnuclear trafficking. Molecular and Cellular Biology 200222 4113-4123. (https://doi.org/10.1128/ MCB.22.12.4113-4123.2002)

144 Kinyamu HK \& Archer TK. Estrogen receptor-dependent proteasomal degradation of the glucocorticoid receptor is coupled to an increase in mdm2 protein expression. Molecular and Cellular Biology 200323 5867-5881. (https://doi.org/10.1128/MCB.23.16.5867-5881.2003)

145 Lesovaya E, Yemelyanov A, Kirsanov K, Popa A, Belitsky G, Yakubovskaya M, Gordon LI, Rosen ST \& Budunova I. Combination of a selective activator of the glucocorticoid receptor Compound A with a proteasome inhibitor as a novel strategy for chemotherapy of hematologic malignancies. Cell Cycle 201312 133-144. (https://doi. org/10.4161/cc.23048)

146 Yemelyanov A, Bhalla P, Yang X, Ugolkov A, Iwadate K, Karseladze A $\&$ Budunova I. Differential targeting of androgen and glucocorticoid receptors induces ER stress and apoptosis in prostate cancer cells: a

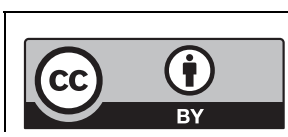

This work is licensed under a Creative Commons Attribution 4.0 International License. 
novel therapeutic modality. Cell cycle 201211 395-406. (https://doi. org/10.4161/cc.11.2.18945)

147 Yemelyanov A, Czwornog J, Gera L, Joshi S, Chatterton RT \& Budunova I. Novel steroid receptor phyto-modulator compound a inhibits growth and survival of prostate cancer cells. Cancer Research 200868 4763-4773. (https://doi.org/10.1158/0008-5472.CAN-076104)

148 Müller S, Hoege C, Pyrowolakis G \& Jentsch S. SUMO, ubiquitin's mysterious cousin. Nature Reviews. Molecular Cell Biology 20012 202-210.

149 Paakinaho V, Kaikkonen S, Makkonen H, Benes V \& Palvimo JJ. SUMOylation regulates the chromatin occupancy and antiproliferative gene programs of glucocorticoid receptor. Nucleic Acids Research 201442 1575-1592. (https://doi.org/10.1093/nar/gkt1033)

150 Druker J, Liberman AC, Antunica-Noguerol M, Gerez J, PaezPereda M, Rein T, Iniguez-Lluhi JA, Holsboer F \& Arzt E. RSUME enhances glucocorticoid receptor SUMOylation and transcriptional activity. Molecular and Cellular Biology 201333 2116-2127. (https:// doi.org/10.1128/MCB.01470-12)

151 Hua G, Paulen L \& Chambon P. GR SUMOylation and formation of an SUMO-SMRT/NCoR1-HDAC3 repressing complex is mandatory for GC-induced IR nGRE-mediated transrepression. PNAS 2015113 E626-E634. (https://doi.org/10.1073/pnas.1522821113)

152 Drean Y Le, Mincheneau N, Goff P Le \& Michel D. Potentiation of glucocorticoid receptor transcriptional activity by sumoylation. Endocrinology 2002143 3482-3489. (https://doi.org/10.1210/ en.2002-220135)

153 Vandevyver S, Dejager L \& Libert C. On the trail of the glucocorticoid receptor: into the nucleus and back. Traffic 201213 364-374. (https://doi.org/10.1111/j.1600-0854.2011.01288.x)

154 Trebble PJ, Woolven JM, Saunders KA, Simpson KD, Farrow SN, Matthews LC \& Ray DW. A ligand-specific kinetic switch regulates glucocorticoid receptor trafficking and function. Journal of Cell Science 2013126 3159-3169. (https://doi.org/10.1242/jcs.124784)

155 Davies L, Paraskevopoulou E, Sadeq M, Symeou C, Pantelidou C, Demonacos C \& Krstic-Demonacos M. Regulation of glucocorticoid receptor activity by a stress responsive transcriptional cofactor. Molecular Endocrinology 201125 58-71. (https://doi.org/10.1210/ me.2010-0212)

156 Kirschke E, Goswami D, Southworth D, Griffin PR \& Agard DA. Glucocorticoid receptor function regulated by coordinated action of the Hsp90 and Hsp70 chaperone cycles. Cell 2014157 1685-1697.

157 Galigniana NM, Ballmer LT, Toneatto J, Erlejman AG, Lagadari M \& Galigniana MD. Regulation of the glucocorticoid response to stress-related disorders by the Hsp90-binding immunophilin FKBP51. Journal of Neurochemistry 2012122 4-18. (https://doi.org/10.1111/ j.1471-4159.2012.07775.x)

158 Oakley R \& Cidlowski J. Cellular processing of the glucocorticoid receptor gene and protein: New mechanisms for generating tissuespecific actions of glucocorticoids. Journal of Biological Chemistry 2011 286 3177-3184. (https://doi.org/10.1074/jbc.R110.179325)

159 Ratajczak T, Cluning C \& Ward BK. Immunophilin chaperones in steroid signalling steroid receptor-associated immunophilins: a gateway to steroid signalling. Clinical Biochemist Reviews 201536 31-52.

160 Hittelman AB, Burakov D, Iñiguez-Lluhí JA, Freedman LP \& Garabedian MJ. Differential regulation of glucocorticoid receptor transcriptional activation via AF-1-associated proteins. EMBO Journal 199918 5380-5388. (https://doi.org/10.1093/emboj/18.19.5380)

161 Ballinger CA, Connell P, Wu Y, Hu Z, Thompson LJ, Yin LY \& Patterson C. Identification of CHIP, a novel tetratricopeptide repeat-containing protein that interacts with heat shock proteins and negatively regulates chaperone functions. Molecular and Cellular Biology 199919 4535-4545. (https://doi.org/10.1128/ MCB.19.6.4535)
162 Ismaili N, Blind R \& Garabedian MJ. Stabilization of the unliganded glucocorticoid receptor by TSG101. Journal of Biological Chemistry 2005280 11120-11126. (https://doi.org/10.1074/jbc.M500059200)

163 Ponting CP, Cai YD \& Bork P. The breast cancer gene product TSG101: a regulator of ubiquitination? Journal of Molecular Medicine 199775 467-469.

164 Helzer KT, Hooper C, Miyamoto S \& Alarid ET. Ubiquitylation of nuclear receptors: New linkages and therapeutic implications. Journal of Molecular Endocrinology 201554 R151-R167. (https://doi. org/10.1530/JME-14-0308)

165 Strohmaier H, Spruck CH, Kaiser P, Won KA, Sangfelt O \& Reed SI. Human F-box protein hCdc4 targets cyclin E for proteolysis and is mutated in a breast cancer cell line. Nature 2001413 316-322. (https://doi.org/10.1038/35095076)

166 Koepp D, Schaefer L, Ye X \& Keyomarsi K. Phosphorylation-dependent ubiquitination of Cyclin E by the SCF-Fbw7 ubiquitin ligase. Science 2001294 173-177. (https://doi.org/10.1126/science.1065203)

167 Malyukova A, Brown S, Papa R, O’Brien R, Giles J, Trahair TN, Dalla Pozza L, Sutton R, Liu T, Haber M, et al. FBXW7 regulates glucocorticoid response in T-cell acute lymphoblastic leukaemia by targeting the glucocorticoid receptor for degradation. Leukemia 2013 27 1053-1062. (https://doi.org/10.1038/leu.2012.361)

168 Verma S, Ismail A, Gao X, Fu G, Li X, Malley BWO \& Nawaz Z. The ubiquitin-conjugating enzyme UBCH7 acts as a coactivator for steroid hormone receptors the ubiquitin-conjugating enzyme $\mathrm{UBCH} 7$ acts as a coactivator for steroid hormone receptors. Molecular and Cellular Biology 200424 8716-8726. (https://doi.org/10.1128/ MCB.24.19.8716-8726.2004)

169 Garside H, Waters C, Berry A, Rice L, Ardley HC, White A, Robinson P \& Ray D. UbcH7 interacts with the glucocorticoid receptor and mediates receptor autoregulation. Journal of Endocrinology 2006190 621-629. (https://doi.org/10.1677/joe.1.06799)

170 Sengupta S, Vonesch JL, Waltzinger C, Zheng H \& Wasylyk B. Negative cross-talk between p53 and the glucocorticoid receptor and its role in neuroblastoma cells. EMBO Journal 200019 6051-6064. (https://doi.org/10.1093/emboj/19.22.6051)

171 Braten O, Livneh I, Ziv T, Admon A, Kehat I, Caspi LH, Gonen H, Bercovich B, Godzik A, Jahandideh S, Jaroszewski L, Sommer T, Kwon YT, Guharoy M, Tompa P \& Ciechanover A. Numerous proteins with unique characteristics are degraded by the $26 \mathrm{~S}$ proteasome following monoubiquitination. PNAS 2016113 E4639-E4647. (https://doi.org/10.1073/pnas.1608644113)

172 Horiguchi J. Clinical usage of Yi-gan san-schizophrenia, borderline personality disorder, dyskinesia etc. Psychiatria et neurologia Japonica 2012114 708-718.

173 Ikarashi Y, Iizuka S, Imamura S, Yamaguchi T, Sekiguchi K, Kanno H, Kawakami Z, Yuzurihara M, Kase Y \& Takeda S. Effects of yokukansan, a traditional Japanese medicine, on memory disturbance and behavioral and psychological symptoms of dementia in thiamine-deficient rats. Biological and Pharmaceutical Bulletin 2009 32 1701-1709.

174 Attele AS, Wu JA \& Yuan CS. Ginseng pharmacology: multiple constituents and multiple actions. Biochemical Pharmacology 199958 1685-1693. (https://doi.org/10.1016/S0006-2952(99)00212-9)

175 Luttrell LM. Minireview: More than just a hammer: ligand 'bias' and pharmaceutical discovery. Molecular Endocrinology 201428 281-294. (https://doi.org/10.1210/me.2013-1314)

176 Sundahl N, Bridelance J, Libert C, De Bosscher K \& Beck IM. Selective glucocorticoid receptor modulation: New directions with nonsteroidal scaffolds. Pharmacology and Therapeutics 2015152 28-41. (https://doi.org/10.1016/j.pharmthera.2015.05.001)

177 De Bosscher K, Beck IM, Ratman D, Vanden Berghe W \& Libert C. Activation of the glucocorticoid receptor in acute inflammation: the SEDIGRAM concept. Trends in Pharmacological Sciences 201637 4-16. (https://doi.org/10.1016/j.tips.2015.09.002) 
178 Patel R, Williams-Dautovich J \& Cummins CL. Minireview: New molecular mediators of glucocorticoid receptor activity in metabolic tissues. Molecular Endocrinology 201428 999-1011. (https://doi. org/10.1210/me.2014-1062)

179 Reichardt SD, Foller M, Rexhepaj R, Pathare G, Minnich K, Tuckermann JP, Lang F \& Reichardt HM. Glucocorticoids enhance intestinal glucose uptake via the dimerized glucocorticoid receptor in enterocytes. Endocrinology 2012153 1783-1794. (https://doi. org/10.1210/en.2011-1747)

180 Louw A, Swart P \& De Kock SS. Mechanism for the stabilization in vivo of the aziridine precursor 2-(4-acetoxyphenyl)-2-chloro-n-methylethylammonium chloride by serum proteins. Science 199753 189-197.

181 Robertson S, Allie-Reid F, Berghe W Vanden, Visser K, Binder A, Africander D, Vismer M, Bosscher K De, Hapgood J, Haegeman G $\&$ Louw A. Abrogation of glucocorticoid receptor dimerization correlates with dissociated glucocorticoid behavior of Compound A. Journal of Biological Chemistry 2010285 8061-8075. (https://doi. org/10.1074/jbc.M109.087866)

182 Dewint P, Gossye V, De Bosscher K, Vanden Berghe W, Van Beneden K, Deforce D, Van Calenbergh S, Muller-Ladner U, Vander Cruyssen B, Verbruggen G, et al. A plant-derived ligand favoring monomeric glucocorticoid receptor conformation with impaired transactivation potential attenuates collagen-induced arthritis Journal of Immunology 2008180 2608-2615. (https://doi.org/10.4049/ jimmunol.180.4.2608)

183 Wüst S, Tischner D, John M, Tuckermann JP, Menzfeld C, Hanisch UK, van den Brandt J, Lühder F \& Reichardt HM. Therapeutic and adverse effects of a non-steroidal glucocorticoid receptor ligand in a mouse model of multiple sclerosis. PLOS ONE 20094 e8202.

184 De Bosscher K, Vanden Berghe W, Beck IM, Van Molle W, Hennuyer N, Hapgood J, Libert C, Staels B, Louw A \& Haegeman G. A fully dissociated compound of plant origin for inflammatory gene repression. PNAS 2005102 15827-15832. (https://doi.org/10.1073/ pnas.0505554102)

185 Rauner M, Thiele S, Sinningen K, Winzer M, Salbach-Hirsch J, Gloe I, Peschke K, Haegeman G, Tuckermann JP \& Hofbauer LC. Effects of the selective glucocorticoid receptor modulator compound a on bone metabolism and inflammation in male mice with collageninduced arthritis. Endocrinology 2013154 3719-3728. (https://doi. org/10.1210/en.2012-2221)

186 Zhang Z, Zhang ZY \& Schluesener HJ. Compound A, a plant origin ligand of glucocorticoid receptors, increases regulatory $\mathrm{T}$ cells and M2 macrophages to attenuate experimental autoimmune neuritis with reduced side effects. Journal of Immunology 2009183 3081-3091. (https://doi.org/10.4049/jimmunol.0901088)

187 Huynh T, Uaesoontrachoon K, Quinn JL, Tatem KS, Heier CR, Van Der Meulen JH, Yu Q, Harris M, Nolan CJ, Haegeman G, et al. Selective modulation through the glucocorticoid receptor ameliorates muscle pathology in mdx mice. Journal of Pathology 2013231 223-235. (https://doi.org/10.1002/path.4231)

188 van Loo G, Sze M, Bougarne N, Praet J, Mc Guire C, Ullrich A, Haegeman G, Prinz M, Beyaert R \& De Bosscher K. Antiinflammatory properties of a plant-derived nonsteroidal, dissociated glucocorticoid receptor modulator in experimental autoimmune encephalomyelitis. Molecular Endocrinology 201024 310-322. (https://doi.org/10.1210/ me.2009-0236)

189 Saksida T, Vujicic M, Nikolic I, Stojanovic I, Haegeman G \& StosicGrujicic S. Compound A, a selective glucocorticoid receptor agonist, inhibits immunoinflammatory diabetes, induced by multiple low doses of streptozotocin in mice. British Journal of Pharmacology 2014 171 5898-5909. (https://doi.org/10.1111/bph.12892)

190 Wilkinson L, Verhoog N \& Louw A. Novel role for receptor dimerization in post-translational processing and turnover of the GRo. Scientific Reports 20188 14266. (https://doi.org/10.1038/s41598018-32440-z)

191 Robertson S, Hapgood JP \& Louw A. Glucocorticoid receptor concentration and the ability to dimerize influence nuclear translocation and distribution. Steroids 201378 182-194. (https:// doi.org/10.1016/j.steroids.2012.10.016)

192 Tiwari M, Oasa S, Yamamoto J, Mikuni S \& Kinjo M. A quantitative study of internal and external interactions of homodimeric glucocorticoid receptor using fluorescence cross-correlation spectroscopy in a live cell. Scientific Reports 20177 4336. (https://doi. org/10.1038/s41598-017-04499-7)

Received in final form 28 September 2018

Accepted 11 October 2018

Accepted Preprint published online 11 October 2018

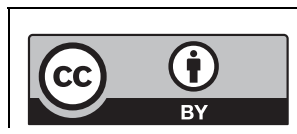

This work is licensed under a Creative Commons Attribution 4.0 International License. 